$$
\text { UNIVERSIDADE DE SÃO PAULO }
$$

FACULDADE DE FILOSOFIA, LETRAS E CIÊNCIAS HUMANAS

DEPARTAMENTO DE LETRAS ORIENTAIS

PROGRAMA DE PÓS-GRADUAÇÃO EM LÍNGUA, LITERATURA E CULTURA ÁRABE

AMANDA AZIS ALEXANDRE

O "torpe Ismaelita cavalleiro": um estudo sobre a presença dos mouros em

Os Lusíadas

São Paulo 


\author{
UNIVERSIDADE DE SÃO PAULO \\ FACULDADE DE FILOSOFIA, LETRAS E CIÊNCIAS HUMANAS \\ DEPARTAMENTO DE LETRAS ORIENTAIS \\ PROGRAMA DE PÓS-GRADUAÇÃO EM LÍNGUA, LITERATURA E CULTURA \\ ÁRABE
}

O "torpe Ismaelita cavalleiro": um estudo sobre a presença dos mouros em

\title{
Os Lusíadas
}

Amanda Azis Alexandre

\begin{abstract}
Versão corrigida da dissertação apresentada ao Programa de PósGraduação em Língua, Literatura e Cultura Árabe do Departamento de Letras Orientais da Faculdade de Filosofia, Letras e Ciências Humanas da Universidade de São Paulo, para obtenção do título de mestre.
\end{abstract}

De acordo:

Orientadora: $\operatorname{Prof}^{\mathrm{a}}$ Dra $^{\mathrm{a}}$ Adma Fadul Muhana

\section{São Paulo}




\section{RESUMO}

Os mouros são personagens vituperados em vários textos produzidos por cristãos, no século XVI ibérico. Esse trabalho tem como objetivo destacar e analisar os vitupérios presentes n'Os Lusíadas. Para isso, utilizaremos as preceptivas que regulam a produção letrada do período, sobretudo a Retórica de Aristóteles e a Institutio Oratoria de Quintiliano, a fim de demonstrarmos quais aspectos considerou o poeta para vituperar os mouros em seu épico.

PALAVRAS-CHAVE: Os Lusíadas, Mouros, Século XVI, Vitupério

Email: $\underline{\text { amandaaziza@usp.br }}$ 


\section{RÉSUMÉ}

Les Maures sont des personnages blamés dans plusieurs textes produits par des chrétiens, au XVI ibérique. Cette recherche a pour but montrer et analyser les blâmes présentes chez Les Lusiades. Pour ce faire, nous utiliserons les oeuvres qui régissent la production lettrée de la période, surtout la Rhétorique d'Aristote et l'Institutio Oratoria de Quintilien, a fin de faire voir les aspects qu'a considérée le poète pour composer les blâmes aux Maures dans son épique. 


\section{AGRADECIMENTOS}

Agradeço à Prof ${ }^{a}$ Adma pela orientação e por haver me apresentado um mundo até então desconhecido para mim. Obrigada pela paciência e pela oportunidade. Agradeço ao Departamento de Letras Orientais, a todos os funcionários e a todos os professores. Agradeço especialmente à Prof ${ }^{a}$ Safa Jubran, pela acolhida carinhosa e pelos conhecimentos e bons momentos compartilhados. Obrigada de todo o coração.

Agradeço aos funcionários da biblioteca Floristan Fernandes, em especial ao Sr. Augusto; aos funcionários do Bandejão, das lanchonetes do depto de Letras, da Eca e das Ciências Sociais. Agradeço também aos funcionários do Uspão e do Cepe. Todos contribuíram de alguma forma para a realização desse trabalho.

Agradeço à Capes, pela bolsa concedida.

Agradeço ao Flávio Reis, cujo auxílio foi decisivo nesses últimos meses. Obrigada Flávio, pela amizade e pela generosidade. Nenhuma palavra poderá expressar minha profunda gratidão.

Obrigada aos queridos Rita de Cássia Gomes, Matias Vale e Gabrielle Borges. Obrigada por estarem sempre ao meu lado.

Obrigada a Wafah El Hage, Veridiana Morais, Denise Lopes e Paula Caffaro. A paixão pelos Estudos Árabes nos uniu, mas agora é apenas um dos alicerces que sustentam nossa amizade.

Agradeço à Prof ${ }^{a}$ Iris Kantor e ao Prof ${ }^{o}$ Leon Kossovitch pelos sábios conselhos dados no exame de qualificação.

Obrigada às professoras Iris Kantor e Maria do Socorro Fernandes por aceitarem compor minha banca de defesa da dissertação.

Por fim agradeço à minha família. Agradeço à minha mãe, minha maior motivação. Ao Ernesto, amigo e incentivador. Aos meus irmãos Adla, Márcio e Mayra, meus amores. Agradeço às minhas primas queridas, especialmente Flávia e Danila, pelo carinho e aos meus tios Paulo e Deli, pelas palavras confortadoras.

Agradeço a meu falecido pai, grande responsável pelo meu amor aos livros... principal responsável pelo meu orgulhoso apego às raízes.

Obrigada. 
"Todas as penas nasceram em carne e sangue, e todos na tinta de escrever misturam as cores do seu afeto" Padre Antônio Vieira 


\section{SUMÁRIO}

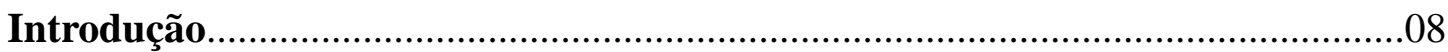

1 - Os Mouros na Produção Letrada do Século XVI...........................................10

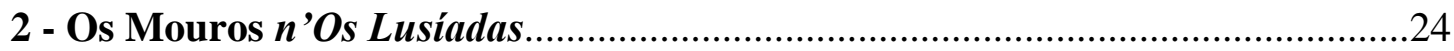

2.1 - A figura do Mouro n'Os Lusíadas a partir dos Lugares de Pessoa de

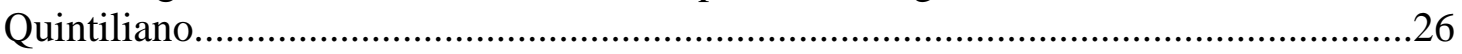

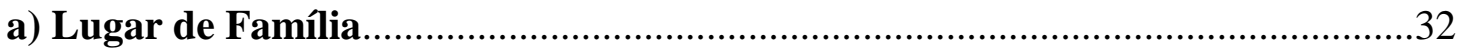

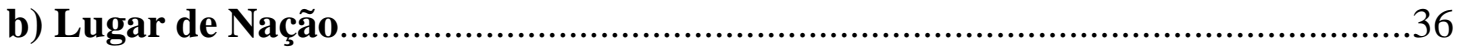

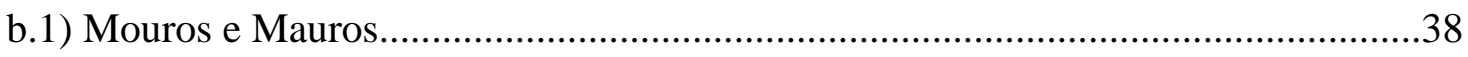

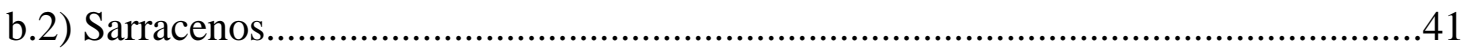

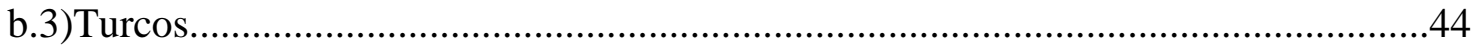

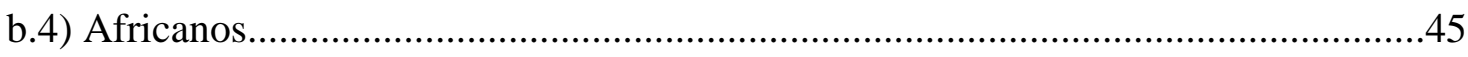

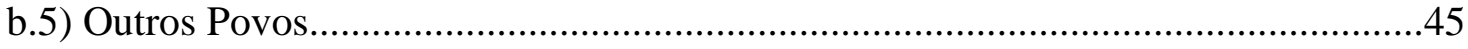

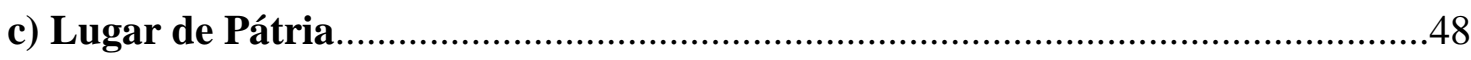

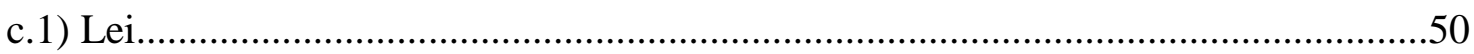

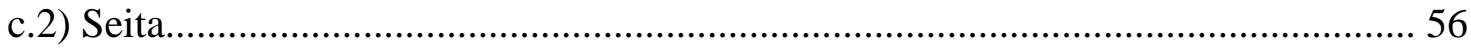

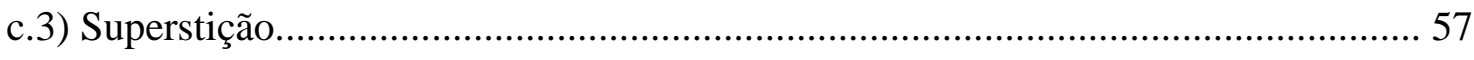

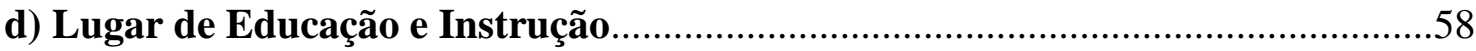

e) Lugar dos Caracteres e Lugar de Palavras e Ações.............................................60

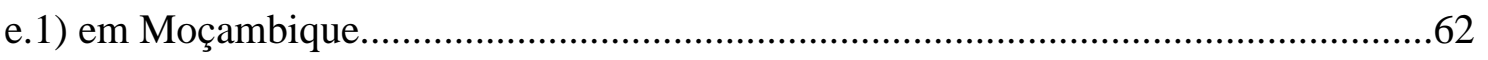

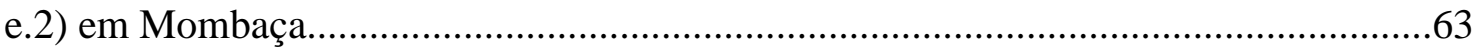

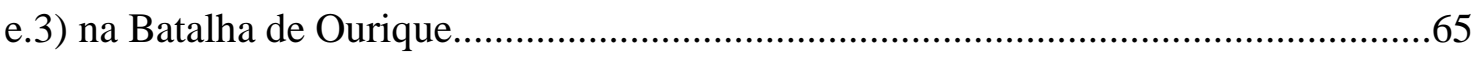

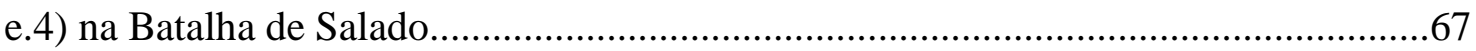

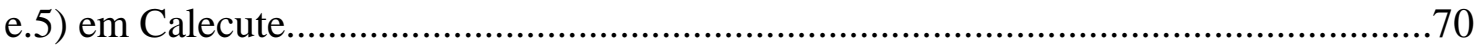

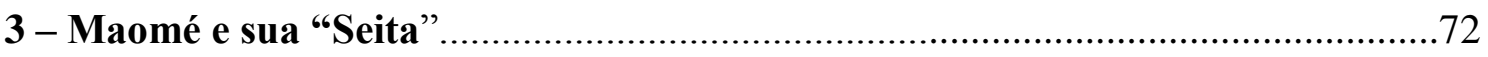

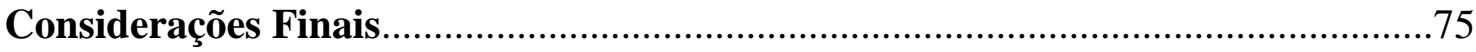

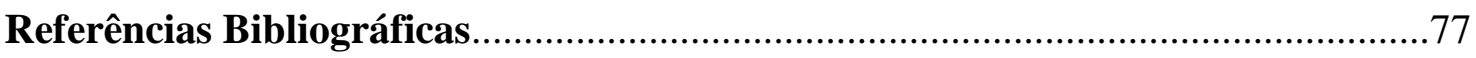




\section{Introdução}

Vós que esperamos jugo e vitupério,

Do torpe Ismaelita cavalleiro:

Do Turco Oriental, e do Gentio,

Que inda bebe o licor do sancto Rio

(Canto I, 8) ${ }^{1}$

Foi devido a versos como esses que decidi verificar o modo como Camões apresenta os maometanos em seu Os Lusíadas. O trecho em questão refere-se à dedicatória do poema e Camões o dedica ao rei D. Sebastião. Este é o "Vós", de quem se espera que domine e vitupere o "torpe Ismaelita", o "Turco Oriental" e o "Gentio". Meu foco será apenas o "torpe Ismaelita", embora, devido a fortes semelhanças no modo de apresentação, eu não pretenda excluir completamente as citações referentes aos outros.

A partir de um cotejo mais atento pude perceber que do primeiro ao décimo canto há referências aos maometanos em Os Lusíadas, em sua maior parte ofensivas, principalmente na narração de batalhas. Referências elogiosas são raras, embora haja. $\mathrm{O}$ rei de Melinde e Monçaide são dois personagens que merecerem do Poeta epítetos elogiosos, apesar de serem maometanos. Quanto ao vitupério, este ocorre por todo o poema. Estão nas falas não só do narrador como também nas falas dos personagens, sejam estes homens ou deuses. No poema, o maometano é o inimigo que deve ser combatido e o Islã é a "Lei maldita" que deve ser extirpada da face da Terra. Essas tópicas permeiam todo o poema.

Ao vituperar o maometano, "torpe Ismaelita", o Poeta não só retoma as preceptivas clássicas de vitupério ao inimigo, tais as fixadas por Aristóteles e Quintiliano, entre outros, como se insere numa tradição que tem no maometano, como se pode perceber nas crônicas medievais e nas canções de gesta dos séculos anteriores, o inimigo-mor da Cristandade.

\footnotetext{
${ }^{1}$ Todas as citações são retiradas da edição fac-similar editada pela Academia Brasileira de Letras em comemoração ao IV centenário da publicação d'Os Lusíadas.
} 
No primeiro capítulo trazemos o inventário de trechos de alguns textos do século XVI, basicamente poemas e crônicas historiográficas, que fazem referências aos maometanos. Selecionamos passagens da Crônica de El-Rei D. Afonso Henriques de Duarte Galvão, da crônica de Rui de Pina, sobre o rei Afonso IV e trechos da Ásia, de João de Barros. Há também trechos de um poema do Cancioneiro de Garcia de Resende sobre a Tomada de Azamor pelo duque de Bragança, duas peças de Gil Vicente, o Auto da Barca do Inferno e Exaltação à Guerra, e, claro, d'Os Lusíadas de Luis de Camões.

As crônicas foram selecionadas devido ao fato de terem servido de possíveis fontes para o poeta, conforme afirmado por José Maria Rodrigues ${ }^{2}$. Já os outros textos foram selecionados por serem obras bem conhecidas e citadas, especialmente o Auto da Barca do Inferno.

No segundo capítulo, citamos e comentamos os versos mais significativos que contêm o vitupério aos maometanos ou à sua Lei, almejando analisá-los, tendo em vista as preceptivas que regem o elogio e o vitupério, tais como a Instituição Oratória de Quintiliano e a Retórica de Aristóteles.

Esse trabalho tem como fim mostrar de que maneira foram os maometanos vituperados em Os Lusíadas. Nosso trabalho não realiza uma análise aprofundada dos mecanismos retóricos utilizados pelo poeta na construção de seu poema, sobretudo, na figuração vituperada dos mouros. O que fizemos foi um modesto levantamento das ocorrências dos vitupérios no poema camoniano e, concluímos serem eles similares aos que ocorrem em outros textos do século XVI.

\footnotetext{
${ }^{2}$ RODRIGUES, José Maria. Fontes d'Os Lusíadas. Lisboa: Atlântida Editora, 1979.
} 


\section{1 - Os Mouros na Produção Letrada do Século XVI}

Os mouros ${ }^{3}$ são personagens de textos escritos por autores cristãos desde o surgimento do Islã, no século sétimo. Percebe-se que, seja em textos poéticos, seja em textos históricos, a presença dos mouros é notada, e na maioria das vezes, o modo como são apresentados é repleto de epítetos injuriosos. Percebe-se ainda que grande parte dos textos em que essa presença é mais constante e significativa pertence ao gênero épico ou historiográfico. Nas descrições de batalhas ou em episódios que as preparam, as comemoram ou as lamentam o mouro é o grande inimigo e, devido a isso, constantemente vituperado. É o que se observa em várias crônicas do período em questão. Embora pertençam a outro gênero que não o épico, nas batalhas narradas nas crônicas tem-se a mesma matéria que compõe o épico e sabendo-se que todas as práticas letradas do período são regidas pelas mesmas preceptivas ${ }^{4}$, pode-se afirmar que o modo como os mouros são apresentados nelas não difere do modo como são apresentados nos textos poéticos. Assim sendo, tanto na crônica de Duarte Galvão, sobre o rei Afonso Henriques quanto na de Rui de Pina, sobre o rei Afonso IV e de João de Barros, sobre os descobrimentos marítimos, identificamos o mouro como inimigo dos cristãos, do mesmo modo que o identificamos em alguns poemas do Cancioneiro de Garcia de Resende, no teatro de Gil Vicente e em Os Lusíadas de Luis de Camões.

Na Crônica de El-Rei D. Afonso Henriques de Duarte Galvão, escrita por volta de 1505, o autor narra a vida e os feitos desse rei, "primeiro Rey que foy de Portugall" ${ }^{, 5}$. Herdado de seu pai, que por sua vez o ganhou como dote de seu sogro pelos serviços prestados à coroa de Castela na luta contra os mouros, o Condado Portucalense que mais tarde se tornaria o reino de Portugal, foi desde cedo objeto de disputa entre D. Afonso Henriques, sua mãe, que se considerava herdeira das terras, e os mouros que lá habitavam desde o século oitavo. Dessa maneira as referências aos

\footnotetext{
3 "Mouro" era o termo mais comumente utilizado para designar os maometanos no século XVI. Devido a isso, o utilizaremos também, sem, contudo assumirmos o caráter pejorativo que a palavra possui nos dias de hoje.

4 “(...) sí extienden sus normas al terreno de la carta, del sermón y de la historia y - (...) al de todo tipo de composicion tanto en prosa como en verso, dado que ambos recursos expositivos eran considerados como formas alternantes de un mismo proyecto" pag. 22. In: ARTAZA, Elena. El Ars Narrandi en el siglo XVI español. Teoria y Practica. Bilbao: Universidade de Deusto, 1989.

${ }^{5}$ GALVÃO, Duarte. Crônica de El-Rei D. Afonso Henriques. Lisboa: Imprensa Nacional-Casa da Moeda, 1995.
} 
mouros são abundantes por toda a crônica; do início, quando se narra o nascimento de Afonso Henriques e sua luta para se firmar o legítimo herdeiro das terras, ao fim, quando seu filho D. Sancho I assume suas responsabilidades no reino e na luta contra os mouros.

Antes mesmo do início da narração, o autor, no Prolloguo, ao deixar expresso o quanto o rei D. Manuel, a quem a obra é dedicada, é merecedor de todas as honras, nos esclarece o motivo de tanto merecimento:

Escusame, Senhor, de seer nem parecer adullaçam, que digo primeiramente vossa sobçessam nestes regnos, per nosso senhor tam claramente querida e hordenada, levamdo pera ssi tamtos que vos nella precediam, segumdo seus juyzos ocultos, porem sempre justos. Escusame o gramde fervor que loguo pos em vosso uirtuoso coraçom, pera seu seruiço, em tirar judeus e mouros destes rregnos por tall, que lançado fora todo judayco e machometico culto, ficasse sôo o uerdadeiro de sua christãa rrelligiam. Escusame isso meesmo uossa perseverante devaçam e cuidado, em proseguir e dobrar per mar e per terra, guerra comtra mouros em as partes dAfrica: do que nam satisfeito uosso magnânimo coraçom e deseo, que sempre há por menos, o muyto de tam santas empresas",

Duarte Galvão utiliza, para se referir às pessoas adeptas ao Islã, o termo "mouro" e para se referir à Lei que seguem, utiliza "machomético culto". Para o cronista, mouros e seu maomético culto, juntamente a judeus e seu judaico culto, devem ser combatidos para que somente a fé cristã prevaleça.

Por levar a palavra de Deus ao mundo "segumdo agora se assaz confirma per vossa navegaçam e comquista”, D. Manuel se assemelha aos apóstolos de Cristo, que saíam pelo mundo a pregar. Mas o papel do infante português aparece como ainda mais importante, pois não se limita a propagar a fé cristã, mas também a combater quem lhe é contrário:

\footnotetext{
${ }^{6}$ GALVÃO, Duarte. Crônica de El-Rei D. Afonso Henriques. Coimbra, Imprensa Nacional-Casa da Moeda, 1995. pag. 03
} 
O quall mistério traz comssigo gramde mostra e prenostico de seer nam soomente pera conuertimento de muitos jmfiees, mas ajmda pera desfazimento e destroiçam da machometica seita, consijrado bem, Deus seja louuado, os começos e preseguimentos de seus maravilhosos feitos ${ }^{7}$

No decorrer da narrativa, o papel dos portugueses como apóstolos de Cristo e defensores da fé; (pormenor que o autor nos adiantou no prólogo ao se referir e dirigir ao representante da nação), é constantemente reiterado. A própria Mãe de Deus aparece em sonho a Egas Moniz, aio de Afonso Henriques e lhe prediz acerca do pupilo:

(...) faze correger a egreia e jmagem feita aa minha homrra e jsto feito, farás hi uigilia, poemdo o menino que crias sobre o altar e sabe que guareçera, e será saao de todo. E nam menos te trabalha de hi auante de ho bem criar e guardar como fazes, porque meu filho quer per elle destroir muitos jmijgos da fee ${ }^{8}$

Profetizado, o fato de Afonso Henriques lutar durante praticamente toda a sua vida contra os mouros, era esperado e foi pelos séculos seguintes, louvado. Um dos eventos mais significativos de sua trajetória foi a célebre batalha de Ourique, eternizada em Os Lusíadas e motivo da primeira épica portuguesa?.

A batalha de Ourique ocorreu aproximadamente no ano de 1139, "nas terras dAlemteio, espiçialmente na comarqua do campo dOurique"10, e foi iniciada, segundo a crônica, devido aos desejos de Afonso Henriques de servir a Deus, pois

Consijderamdo elle que nam deuia nem podia milhor empregar o bem e homrra que seu pay e elle gaanharam, que em seruiço de nosso

\footnotetext{
${ }^{7}$ GALVÃO, Duarte. Crônica de El-Rei D. Afonso Henriques. Coimbra, Imprensa Nacional-Casa da Moeda, 1995. Pag. 05.

${ }^{8}$ Idem, pag. 16.

${ }^{9}$ Há discussões a respeito da seguinte questão: houve ou não uma épica medieval portuguesa? Antonio Saraiva acredita que a Batalha de Ourique e outras histórias que têm em Afonso Henriques o personagem principal podem sim fazer parte de uma tradição épica medieval em Portugal. SARAIVA, Antonio José. A Épica Medieval Portuguesa. Biblioteca Breve 29. Lisboa, Instituto de Cultura e Língua Portuguesa, 1991.

${ }^{10}$ GALVÃO, Duarte. Crônica de El-Rei D. Afonso Henriques, pag. 46.
} 
Senhor, de cuja mãao o tijnham rreçebido: e como nam auia emtam nenhuu serviço de Deus mais necessário em Espanha ocupada de mouros, que seerem guerreados e lançados fora della, segumdo fora sempre seu propósito e voomtade ${ }^{11}$

A região do Alentejo foi escolhida por duas razões, conforme conta Duarte Galvão: a primeira devido ao fato de a região ser bastante povoada e dispor com poucas fortalezas, o que traria aos ofensores "assaz mantijmentos e presas"; a segunda, e principal, porque Afonso Henriques desejava pelejar com o rei Ismar e derrotá-lo, o que lhe daria controle sobre toda Estremadura.

O dito rei Ismar, ao saber do ataque pretendido por Afonso Henriques, convocou toda a "mourama dos Algarves e doutras partes darredor", que prontamente lhe atendeu. E foram tantos os mouros reunidos que os cristãos se viram em minoria, o que causou grande temor nas hostes cristãs. Afonso Henriques, ao perceber o quanto seus cavaleiros estavam amedrontados falou-lhes, num discurso inflamado que vale a pena reproduzir

Meus bõos vassallos e amigos, mujtos vos deve de lembrar a tençam e deseios com que partimos de Coymbra, pera servir a Deus e pugnar por sua samta ffee, comtra estes seus jmijguos e nossos (...). Deus por sua piedade numqua abrio mãao dos que nelle esperam, nem pera dar o tolher a quem lhe praz uitoria, ha mester poder de mais nem menos gente. Lembrevos quamtas vezes e em quamtos lugares pelleiaram nossos antecessores com estes emijgos da ffee, e os uemçeram, poucos a mujtos (...) e tamto mais davamtagem de nossos jmijgos deve seer nosso coraçam e esforço, quamto teemos mais justas causas e rrezam da pelleia. Nos pelleiamos por Deus, polla ffee, pella verdade. Estes arrenegados que veedes, pelleiam comtra Deus, pella falssidade. Nos por nossa terra, elles polla que nos tem forçada e querem forçar. Nos pello sangue e uimgamça de nossos amteçessores, elles por ajmda espargerem cruellmente o nosso. Nos por nossos pais, nossas pessoas, nossas molheres e filhos em liberdade, elles a nos todos em seu cativeiro. A terra que oje em obra tem e pessuem em Africa e em Espanha, nossa foy, e a christaãos por nossos peccados a tomaram: e

${ }^{11}$ GALVÃO, Duarte. Crônica de El-Rei D. Afonso Henriques. Pag 48. 
aguora que Deus quer que a cobremos com seu desfazimento e destroiçam, nam desfalleçamos aa voomtade de Deus e a tamanho bem nosso. Do quamta merçee nos Deus faz cavalheiros, e a quamto bem nos chegou, se lho bem conhecermos: chegounos a huu dia e feito tam glorioso, quamto cavalheiros nam poderiam nem saberiam deseiar: chegounos a pelleiarmos por elle e por nos, pelleia sua e nossa comtra çimquo reis mouros jmijgos da sua samta ffee em que nos elle salvou, pelleia em que mataremos seguros de culpa, morreremos mais seguros de gallardam. Matamdo, ganharemos terra e homrra temporal, morremdo guanhamos o çeeo e gloria eterna. Matamdo tolhemos a vida a nossos jmijgos, morremdo damola a nos pera sempre ${ }^{12}$.

Esse trecho é elucidativo. Nele detectamos grande parte das tópicas referentes aos mouros no período: são arrenegados, inimigos da fé, infiéis. Matando-os livra-se o mundo do mal que eles representam; morrendo-se na luta contra eles, garante-se a vida eterna.

Imbuídos de coragem, os guerreiros têm ainda um novo motivo que não os deixa mais duvidar da vitória que os espera: Cristo aparece a Afonso Henriques. Graças a esse milagre, que os animou e encheu de certezas, apesar de haver, (segundo afirma Galvão e o reafirma Camões), cem mouros para cada cristão, os cristãos vencem e Afonso Henriques é proclamado rei.

No Canto III d'Os Lusíadas, a batalha de Ourique é narrada por Vasco da Gama ao rei de Melinde. Os mouros, "exprimentados nos perigos" (III, 44) e com "A ajuda convocando do Alcorão" (III, 50) combatem bravamente o "povo bautizado" (III, 43) que "Em nenhua outra cousa confiado, / Senão no summo Deos que o Ceo regia" (III, 43) lutava. Mas de nada vale o alarido dos perros (III, 48), pois os cristãos vencem e “(...) perde o campo o exército nefando" (III, 52).

A Batalha de Salado, narrada na Crônica de ElRey Afonso IV de Rui de Pina e também narrada por Camões n'Os Lusíadas, não difere muito da de Ourique, apesar de

\footnotetext{
${ }^{12}$ GALVÃO, Duarte. Crônica de El-Rei D. Afonso Henriques. Pag. 53.
} 
nela os ofensores serem os mouros não mais os cristãos, que queriam retomar as terras que por direito consideravam suas. ${ }^{13}$

Na crônica, antes da batalha final, um episódio se destaca. Alguns cristãos montavam guarda no Estreito, a fim de impedir que os mouros o atravessassem e chegassem às terras cristãs, mas uma tempestade agitou o mar matando vários deles afogados e fazendo com que outros fossem presos pelos mouros e levados para a cidade de Aljazira. Muitos dos presos, temerosos, se converteram ao Islã, para horror de Rui de Pina que assim descreve o fato:

(...) e destes alguns herão fracos de coração e pouco de coraçam à fee vierão ante Alibohaçem, que com promessas, e grandes esperanças os exortava, pera tomarem a ley de Mafamede, dizendo que por obras já muy claras, e por tais milagres que vião, já verião que sua ley hera milhor que a de IESU Christo, pois não podião negar que as ondas do mar, só por que Deos o queria, peleijavão já pellos Mouros, e lhes trazião as suas mãos os Christãos seus imigos, e por isso muytos que avião mayor medo à morte, e tormentos dos corpos, que à perda das Almas, escolherão por sua condenaçam sua ceita errada, e se tornarão Mouros ${ }^{14}$

Reprovando tal acontecimento, o cronista continua na página seguinte:

(...) e cõ tudo elRey Mouro não deyxava de cõfirmar seus sequazes em sua danada porfia, e reduzir a ella com falsas esperanças, os fracos Christãos, não vendo como cegos nem sabendo como ignorantes, aquelle atalho, do verdadeyro juízo de Deos, e nosso Senhor IESUS Christo, que sem muyta tardança, loguo mostrou na grande, e fermosa batalha, em que com tanto seu estrago delles mesmos infieis, deu aos Christãos tam segura victoria como adiante se dirá. ${ }^{15}$

\footnotetext{
${ }^{13}$ "loguo de terminarão passar ambos em Espanha, achando qua seus direytos porque de direyto ella Ihe pertencia..." Chronica de ElRey Dom Afonso o Quarto do Nome, e Settimo dos Reys de Portugal (1440-1522). In: Crônicas de Rui de Pina. Porto: Lello e Irmão-Editores, 1977.

${ }^{14}$ Idem, pag. 433.

${ }^{15}$ Idem, pag. 434.
} 
"Ceita errada", "danada porfia", "cegos", "ignorantes", "infiéis"; tais sãos os epítetos recebidos pelos mouros em sua descrição. Estes têm contra si os reis de Portugal Afonso IV e o de Castella, Afonso XI. Antes que a batalha de Salado tivesse início, no dia 28 de outubro de 1340, foi celebrada uma missa, na qual os reis e o exército rezaram:

Dom Gil Arcebispo de Toledo aquella ora disse Missa mayor, e fez a todos hum sermão, pera o tempo tam devoto, e tam conveniente, e no cabo delle disse tam singulares orações adereçadas à piedade de Deos, e outorgou tantas Indulgencias, e remições de peccados, por vertude da Sancta Cruzada que tinha nas mãos, que nom ouve em algum Christão olhos tam duros, que cõ lágrimas de esforço nam testemunhasse dezejar de morrer por serviço de Deos, e salvando a Alma atalhar a perdiçam de Espanha que ante si viam. ${ }^{16}$

O Arcebispo reconhece ser a Batalha de Salado uma "Sancta Cruzada" e, por isso, outorga ao exército "Indulgencias, e remições dos peccados". Já na narração da Batalha, o autor diz que os "Mouros imigos da Fee e da Cruz", apesar de serem muitos, a ponto de os cristãos acharem que a quantidade aparente deles era fruto de encantamento, "que os Mouros muyto sabiam", foram derrotados após sangrento combate, no qual lutaram bravamente todos os combatentes. Rui de Pina conta que morreram 450 mil mouros e 20 cristãos.

$\mathrm{Na}$ narração da batalha feita por Camões, temos um dos momentos mais belos de todo o épico. D. Maria, esposa do rei Afonso XI de Castela, vai a Portugal a pedido do marido para pedir auxílio a seu pai, D. Afonso IV, na luta contra os mouros que invadiram as terras castelhanas

Canto III, 103

"Quantos povos a terra produzio/De Africa toda gente fera e estranha,/O grão Rei de Marrocos conduzio/ Pera vir possuir a nobre Espanha:/ Poder tamanho junto não

\footnotetext{
16 Chronica de ElRey Dom Afonso o Quarto do Nome, e Settimo dos Reys de Portugal (1440-1522). In: Crônicas de Rui de Pina. Porto: Lello e Irmão-Editores, 1977. pag 446
} 
se vio/ Despois que o salso Mar a terra banha./ Trazem ferocidade, e furor tanto,/Que a vivos medo, e a mortos faz espanto" 17

Acedendo ao pedido da filha, o rei de Portugal Afonso IV reúne um exército e vai a Castela, em socorro do genro.

Após sangrenta batalha, que os mouros consideravam já ganha, os cristãos vencem. Favorecidos pela Graça divina, os cristãos são os vitoriosos e os mouros, "cega gente", derrotados e seu poder "grande e horedo (...) desbaratado" (Canto III, 115).

João de Barros na primeira Década de sua Ásia faz também inúmeras referências aos mouros, principalmente nas descrições das batalhas. No entanto, o modo como inicia seu texto é significativo:

\begin{abstract}
Alevantado em a terra de Arábia aquelle grãde antechristo Mafamede, quasi nos annos de quinhentos noventa e três de nossa redençam, assy lavrou a fúria de ser ferro e fogo de sua infernal secta, por meyo de seus capitães e calyfas: que em espaço de cem annos, conquistaram em Asia toda Arabia, e parte da Syria e Pérsia, e em Africa todo Egypto daquem e dalem Nilo (...) Os quaes a força de armas devastando e asolando as terras, se fizeram senhores da mayor parte da Mauritania Tingitania, em que se compreendem os reynos de Fez e Marrocos: sem até este tempo a nossa Europa sentir a perseguiçam desta praga ${ }^{18}$.
\end{abstract}

Ele inicia sua obra falando sobre o maior inimigo da Cristandade do momento: a seita de Maomé. Narra sua origem e sua rápida expansão, até sua chegada à Europa, que devido aos pecados de Espanha, recebeu esse mal em seu território. Durante anos os cristãos tentaram recobrar suas terras, a começar pelo príncipe dom Pelágio ${ }^{19}$, chegando a Dom Afonso Henriques, de Portugal "O qual dote e herança, parece q foy dado com tal bençam per este catholico rey dom Afonso: que todolos seus descendentes que a herdassem, sempre tivessem continua guerra com esta pérfida gente dos Arabios."20

\footnotetext{
${ }^{17}$ CAMÕES, Luis de. Os Lusíadas.

${ }^{18}$ BARROS, João de. Ásia. Primeira Década. Coimbra: Imprensa Nacional-Casa da Moeda, 1932. Pag. 05.

${ }^{19}$ Idem, pag. 05.

${ }^{20}$ Idem, pag. 12.
} 
Tendo como objetivo narrar e exaltar os descobrimentos portugueses, João de Barros elege a pessoa do Infante Dom Anrrique como seu personagem principal por vários capítulos. Ele conta que o Infante desejava fazer guerra aos infiéis, pois além da "natural inclinaçam" que sempre teve para exaltar a fé católica, era administrador e governador da "ordem da cavallaria de nosso senhor Iesu Christo, que elRey Dom Dinis seu tresavo pera esta guerra dos infiéis ordenou e novamete constituyo" ${ }^{21}$. E como no seu tempo, já não havia mouros em Portugal, foram em sua busca em terras africanas:

E se ante da tomada de Cepta, nã pos em obra este seu natural desejo, foy porque já em seu tepo neste reyno nam avia mouros que conquistar: porque os reis seus avós (segundo dissemos) a poder de ferro os tinha lançado além mar em as partes de Africa. E pera os elle lá jr buscar a comprir o q the ficara por avoego, e covinha per officio: era necessário passar tam poderosamete como fez seu padre na tomada de Cepta. (...)Nosso senhor como por sua misericórdia queria abrir as portas de tanta infidelidade e idolatria pera salvaçam de tantas mil almas que o demônio no centro daquellas regioes e províncias bárbaras tinhas cativas, sem notícias dos méritos da nossa redeçã... ${ }^{22}$

E se até o momento, as partes de África e Ásia ainda não tinham sido descobertas, ficando "cerradas e de nós bem esquecidas" era porque ainda não havia surgido a pessoa escolhida por Deus para essa missão. Dom Anrrique era o escolhido, e Dom Manuel, seu continuador.

Porque tam grande cousa como era a edificaçam da sua jgreja nestas partes da jdolatria, convinha $\mathrm{q}$ fosse per huu baram tam puro, tam limpo, e de coraçam tam virginal como foy este jfante dom Anrrique que abrio os alicéces della, e per outro tam christianissimo e zelador da Fe e honrra de deos como foy el Rey dom Manuel seu sobrinho e neto adoptivo: que depois como adiante veremos muyto trabalhou na edificaçam desta igreja oriental, metendo grande parte do povo

${ }^{21}$ BARROS, João de. Ásia. Pag. 12.

${ }^{22}$ Idem, pags. 12-14. 
jdolatra em o curral do senhor, e como huu novo apóstolo levou o seu nome per todalas gentes ${ }^{23}$

Obra de devoção, portanto, a expansão marítima portuguesa teve seu inicio na luta contra os mouros, inimigos da fé cristã, segundo o cronista. As regiões conquistadas eram submetidas às leis e à fé do reino português e as práticas devotas que não fossem cristãs eram extirpadas para que a ortodoxia prevalecesse. No relato da Tomada de Azamor isso se torna perceptível. Assim que os portugueses venceram a batalha e renderam toda a província de Aduecala, da qual fazia parte Azamor, consagraram a mais importante mesquita do local

(...) e na mezquita mor mandasse concertar hum altar pera se nelle dizer naquelle dia Missa, à qual cõ ajuda de Deos elle seria presente. Ho q assi feito ho Duq entrou na cidade com há companhia que pera isso ordenou, e fez logou consagrar há mezquita, a que pos nome da advocaçam do Spiritu sancto ${ }^{24}$

Tal episódio aparece também no Cancioneiro de Garcia de Resende. Cantiga composta por Luis Anriquez foi dedicada ao Duque de Bragança, responsável pela Tomada. Com significativo teor épico, a cantiga narra desde a saída do duque de Portugal, empreendedor dessa "santa viajem", até a sua volta triunfante a Portugal. Mais uma vez os mouros aparecem como inimigos e sua lei como errada e vã, já que nas batalhas não favorece seus adeptos:

\footnotetext{
Pelo qual logo sem mais dar vogar

o jentil do Tite foi despovoado,

de medo cortado leixaram logar

tee serem per pazes a ele tornado,
}

\footnotetext{
${ }^{23}$ BARROS, João de. Ásia. Primeira Década. Coimbra: Imprensa Nacional-Casa da Moeda, 1932. Pag. 25. ${ }^{24} \mathrm{GOIS}$, Damião de. Cronica do Felicíssimo Rei D. Manuel. Parte III. Nova edição conforme a primeira de 1566. Coimbra: Por ordem da Universidade, 1954. Pag. 88.
} 
Ca viram seu feito ir tam mal parado

que desesperaram de bem esperar,

Seria Mafoma bem pouco louvado,

pois nele socorro se nam pod'achar. ${ }^{25}$

O autor apresenta a diferença entre os mouros de Azamor, em maior quantidade, e os cristãos que os atacavam como sendo não apenas numérica, mas também de caráter: os mouros eram covardes e se preocupavam em salvar a própria vida, mais que a de seus próprios filhos:

Os mouros de dentro que viram crecer

seu mal e seu dano, sem bem esperar,

com grande temor das vidas perder,

leixaram cidade por vidas salvar

Fugindo sem tento, com tal pressa dar,

qu'ò sair da porta muitos se matavam

os pais pelos filhos se non esperavam,

molher por marido podia aguardar ${ }^{26}$

A dramaticidade do episódio reforça a justiça da vitória cristã. Pais que abandonam os filhos merecem o mal que sobre si mesmos caia.

No entanto, apesar das referências aos mouros serem mais comuns e constantes em narrativas de teor épico, não é só nestas que as encontramos. Elas estão presentes em

\footnotetext{
${ }^{25}$ Cancioneiro Geral de Garcia de Resende. Vol. II. Fixação do Texto por Aida Fernanda Dias. Lisboa: Imprensa Nacional-Casa da Moeda, 1990.

26 Idem.
} 
outros gêneros, como no teatro de Gil Vicente e nos episódios líricos de Os Lusíadas, como o de Inês de Castro ou o de invectivas, como o do Velho do Restelo.

No Auto da Barca do Inferno, embora não se encontre a palavra "mouro", sabemos que, no final da peça, quando os guerreiros cruzados embarcam na barca do Paraíso, é por lutar contra ele que eles têm sua "passagem" garantida. Os cavaleiros embarcam na barca sem qualquer tipo de objeção, nem dos outros personagens impedidos de embarcar, nem do diabo:

ANJO Ć Cavaleiros de Deos
a vós estou esperando
que morrestes pelejando
por Cristo senhor dos céus
Sois livres de todo o mal
santos por certo sem falha
que quem morre em tal batalha
merece paz eternal. ${ }^{27}$

Em outra peça, chamada Exortação à Guerra, a guerra em questão é também contra os mouros. O dramaturgo exorta o povo português a vender seus pertences para financiar essa guerra, que é de devoção. Anibal, famoso guerreiro, fala:

$$
\begin{aligned}
& \text { Deveis senhores esperar } \\
& \text { em Deos que vos há de dar } \\
& \text { toda África na vossa mão }
\end{aligned}
$$

África foi de cristãos

\footnotetext{
${ }^{27}$ Auto da Barca do Inferno. In: As Obras de Gil Vicente. Vol 1. Centro de Estudos de Teatro, Imprensa Nacional-Casa da Moeda, 2002.
} 
mouros vo-la tem roubada

capitães pode-lh'as mãos

que vós vereis mais louçãos

com famosa nomeada.

Ó senhoras portuguesas

gastai pedras preciosas

donas, donzelas, duquesas

que as tais guerras e empresas

são propriamente vossas

É guerra de devação

por honra de vossa terra

cometida com rezão

formada com descrição

contra aquela gente perra

(...)

Sua alteza detremina

por acrescentar a fé

fazer da mezquita sé

em Fez por graça divina

Guerra guerra mui contina

é sua grande tenção ${ }^{28}$.

${ }^{28}$ Exortação da Guerra. In: As Obras de Gil Vicente. Vol. 1. Centro de Estudos de Teatro, Imprensa Nacional-Casa da Moeda, 2002. Pags. 678-680. 
No episódio de Inês de Castro há dois momentos em que há referência aos mouros. No primeiro está escrito "Que furor consentio, que a espada fina,/ Que pode sustentar a grande peso/ Do furor Mauro, fosse alevantada/ Contra hua fraca dama delicada?" (Canto III,123) ${ }^{29}$; e no segundo, numa fala da própria Inês: "E se vencendo a Maura resistência,/ A morte sabes dar com fogo e ferro" (Canto III, 128) ${ }^{30}$. Os dois momentos tratam de contextos bélicos, no entanto, lírico é o episódio e por isso, percebe-se o quanto a presença dos mouros fazia-se notar nas mais diversas situações.

Já no episódio do Velho do Restelo, as passagens referentes aos mouros não apenas os citam, mas incitam:

\section{Canto IV, 100}

"Não tens junto com tigo o Ismaelita/ Com quem sempre terás guerras sobejas?/ Não segue elle do Arábio a ley maldita,/ Se tu polla de Christo só pellejas?/ Não tens cidades mil, terra infinita,/ Se terras e riqueza mais desejas?/ Não he elle por armas esforçado/ Se queres por victórias ser louvado?"31

Canto IV, 101

"Deixas criar aas portas o inimigo,/ Por yres buscar outro de tão longe" (IV, $101)^{32}$

Nos trechos citados percebemos que é o maometismo a "lei maldita" que deve ser combatida para que a lei de Cristo prevaleça. Mais uma vez as tópicas operam.

\footnotetext{
${ }^{29}$ CAMÕES, Luis de. Os Lusíadas.

30 idem.

31 idem.

32 idem..
} 


\section{2 - Os Mouros n'Os Lusíadas}

Desde o surgimento do Islã, os mouros têm sido personagens de textos escritos nos mais diversos gêneros pelos cristãos, como foi visto anteriormente. Inicialmente, retratados como ameaça militar, vistos como "castigo divino pelos pecados cometidos pelos cristãos" ${ }^{33}$. Posteriormente, tal visão não só se manteve como se amplificou. Os mouros já não eram simplesmente uma ameaça militar, mas também uma ameaça à ortodoxia.

Tal caracterização pode ser constatada em parte significativa da produção letrada da época, como por exemplo, nos textos citados por nós no primeiro capítulo. E o que se percebe é que em todos eles, os mouros são vituperados, ou seja, têm seus vícios apontados, execrados e suas ações reprovadas.

A freqüência com que esse vitupério aparece nos textos do século XVI e anteriores estabelece a tópica do "mouro-inimigo" e se deve a uma série de fatores. Situações históricas específicas, especialmente na Península Ibérica, contribuíram para que os mouros fossem retratados nas obras como adversários. Sabe-se que desde o século oitavo, muitos deles se estabeleceram na Península e mantiveram por alguns séculos grande parte de suas terras sob dominação. Dessa forma, os cristãos nativos e seus descendentes, viam neles os invasores que ameaçavam seus costumes e punham em risco suas vidas e propriedades. Com o início das Cruzadas essa animosidade se tornou ainda mais acirrada a ponto de, após as chamadas Guerras de Reconquista, os mouros serem expulsos de todo o território peninsular. Nas poesias e peças de teatro, os mouros são os principais inimigos dos cristãos. As crônicas medievais que narram a História dos primeiros reis portugueses ou espanhóis têm na descrição da luta contra os mouros seus momentos épicos. Os tratados políticos e teológicos trazem uma preceituação ${ }^{34}$, especialmente após a Contra-Reforma, que fundamentou as medidas tomadas contra os mouros nos reinos ibéricos ${ }^{35}$. Os tratadistas do século XVI apropriaram-se da noção medieval de ética cristã, baseada principalmente no que foi afirmado por São Tomás de Aquino, como fundamento da política ${ }^{36}$. No dizer de João

\footnotetext{
${ }^{33}$ TOLAN, John. Les Sarrasins. L'islam dans l'imagination européenne au Moyen Âge. Paris, Aubier, 2003. E também nas falas de Afonso Henriques, conforme a crônica de Duarte Galvão.

${ }^{34}$ Que, na verdade, atingiu a toda a prática letrada.

${ }^{35}$ Como a expulsão, promulgada em 1496 por D. Manuel. BOUCHARB, Ahmed. Os pseudomouriscos de Portugal no speculo XVI. Lisboa, Hugin Editores, 2004.

${ }^{36}$ Sto Tomas de Aquino (De regno, II,2). Professor João Adolfo Hansen: Anotações de aula, 2008.
} 
Adolfo Hansen, para o escolástico, a vida virtuosa é a vida dedicada a Deus e ao que Ele deseja:

(...) Mas parece que o fim da multidão agrupada em sociedade é o de viver segundo a virtude. Os homens, com efeito, reúnem-se para levar juntos uma vida boa, o que não podem atingir vivendo isolados. Ora, é a vida segundo a virtude que é boa. A vida virtuosa é, portanto, o fim da sociedade humana. (...) Mas porque o homem, vivendo segundo a virtude, está ordenado para um fim ulterior que consiste no gozo de Deus (...) é preciso que a multidão humana tenha o mesmo fim que o indivíduo. O fim último da sociedade não é, portanto, viver segundo a virtude mas, pela vida virtuosa, atingir o gozo de Deus ${ }^{37}$

Se o Islã é uma afronta a Deus, seus adeptos são viciosos. Sendo assim, precisam ser eliminados do "Corpo Místico", que é o Estado; pois representam a desordem (a heterodoxia) e colocam em risco a harmonia necessária para que a paz seja mantida. Sua eliminação, seja pela conversão, pela expulsão ou pela morte, assegura o Bem Comum. Este, como forma de transcender as vontades individuais, é o princípio que rege o governo dos estados cristãos. Todos os membros do "Corpo", rei e súditos, devem assumir sua responsabilidade na sua manutenção. Dessa forma, o Bem Comum é estabelecido e a vontade de Deus, que é expressa pelas leis do Reino, ${ }^{38}$ é atendida e obedecida $^{39}$.

A poesia não estava alheia a esses pressupostos. Os princípios retórico-poéticos que a regiam incorporaram essas redefinições, atendendo a uma moral cristã cada vez mais atuante e vigilante. Os Lusíadas situam-se nesse contexto, é o que abordaremos detidamente a seguir.

\footnotetext{
${ }^{37}$ HANSEN, João. Notas de aula, 2008.

${ }^{38}$ Francisco Suárez (De Legibus), HANSEN, João. Anotações de aula, 2008.

39 idem.
} 
2.1 - A figura do Mouro n'Os Lusíadas a partir dos Lugares de Pessoa de Quintiliano

Os Lusíadas pertencendo ao gênero poético épico, possuem elementos dos gêneros retóricos, especialmente do deliberativo e do demonstrativo. Além disso, como obra do século XVI, assume as determinações das preceptivas seiscentistas que preceituam o utilitas horaciano e o tríplice ofício do movere, docere e delectare.

Segundo o objeto da imitação, o épico se destina à imitação de homens superiores $^{40}$, superiores a nós, e de suas ações valorosas. Nas palavras de Tasso, a poesia épica é, portanto: “imitatore d'azione illustre, grande, e perfetta fatta, narrando con altissimo verso, affine di muovere gli animi colla maraviglia; e di giovare in questa

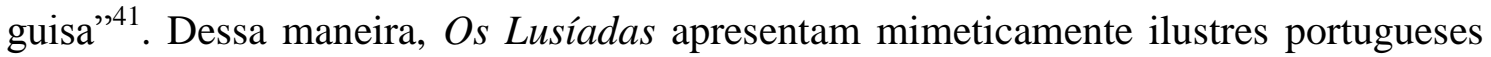
agindo nos empreendimentos marítimos, lutando contra as adversidades naturais e contra os inimigos de Portugal. No entanto, o poema, assim como todas as obras eruditas produzidas no Portugal do século XVI, possui, além das características do gênero a que pertence, características de outros gêneros discursivos, em menor ou maior grau. Na proposição, na dedicatória e nos versos finais do poema, sobressaem características do gênero deliberativo. O poeta intenta persuadir D. Sebastião, a quem o poema é dedicado, a empreender uma nova incursão ao Marrocos e continuar, a exemplo de seus antecessores, a luta contra os Mouros e outros "inimigos da Fé Católica" e a dilatação da mesma.

\section{Canto I, 6}

"E vós ó bem nascida segurança/ Da Lusitana antiga liberdade,/ E não menos certíssima esperança/ De aumento da pequena Christandade,/ Vós, ó novo temor da Maura lança,/ Maravilha fatal da nossa idade,/ Dada ao mundo por Deos, que todo o mande; / Pera do mundo a Deos dar parte grande"

\footnotetext{
40 ARISTÓTELES. Poética. Tradução e Comentários de Eudoro de Souza. São Paulo. Coleção Os Pensadores, Abril Cultural, 1977.

41 TASSO, Discorsi del poema eroico, I, p. 354. Citado por MUHANA, Adma. A Epopéia em prosa seiscentista. Sâo Paulo, UNESP, 1997.
} 


\section{Canto I, 8}

"Vós, poderoso Rei, cujo alto Imperio/ O Sol logo em nascendo vê primeiro/ Veo também no meio do Hemispherio/ E quando dece o deixa derradeiro;/ Vós, que esperamos jugo e vitupério/ Do torpe Ismaelita cavalleiro,/ Do Turco Oriental, e do Gentio/ Que inda bebe o licor do sancto Rio"

Canto I, 15

"E em quanto eu estes canto, e a vós não posso,/ Sublime Rei - que não me atrevo a tanto - / Tomai as redeas vós do Reino vosso:/ Dareis matéria a nunca ouvido canto./ Comecem sentir o peso grosso/ - Que pólo mundo todo faça espanto - / De exércitos e feitos singulares/ De Africa as terras e do Oriente os mares"

O poeta, em meio a elogios, instiga $D$. Sebastião a fazer com que seu nome supere o de seus antepassados e que seus feitos sejam tais que mereçam um "nunca ouvido canto", superior a este que o poeta agora canta.

Nos últimos versos das derradeiras estâncias, continua o poeta:

Canto X, 146

"E não sei por que influxo de destino/ Não tem hum ledo orgulho e geral gosto,/ Que os ânimos levanta de contino/ A ter pera trabalhos ledo o rosto./ Por isso vós, ó Rei, que por divino/ Conselho estais no régio posto/ Olhais que sois - e vede as outras gentes - Senhor só de vassalos excellentes"

Canto X, 147

“Olhai que ledos vão por varias vias,/ Quaes rompentes liões e bravos touros,/ Dando os corpos a fomes e vigias,/ A ferro, a fogo, a setas e pelouros,/ A quentes regiões, a plagas frias/ A golpes de Idólatras e de Mouros,/ A perigos incógnitos do mundo,/ A naufrágios, a peixes, ao profundo"

E nos versos seguintes, o poeta pede que os esforços dos valorosos portugueses sejam reconhecidos e recompensados, pois "com seu sangue intrépido e fervente/ Estendem não somente a lei de cima,/ mas inda vosso império preeminente" (Canto X, 151). Ou seja, dilatam não apenas de Fé, mas também o Império. E pede mais, pede que o Rei ouça somente os conselhos dos "experimentados"; pois a experiência ensina 
mais que os sonhos, a imaginação e o estudo ${ }^{42}$. Para fazer com que seus conselhos sejam acatados, o poeta, então, se vale da tópica da modéstia ${ }^{43}$ e, ao mesmo tempo, se qualifica como conselheiro ideal:

Canto X, 154

"Mas eu que fallo, humilde, baxo, rudo,/ De vós não conhecido, nem sonhado?/ Da boca dos pequenos sei com tudo/ Que o louvor sae as vezes acabado./ Nem me falta na vida honesto estudo/ Com longa experiência misturado,/ Nem engenho, que aqui vereis presente,/ Cousas que juntas se achão raramente"

Canto X, 155

"Pera servir-vos, braço as armas feito;/ Pera cantar-vos, mente ás Musas dada;/ Só me fallece ser a vós acceito,/ De quem virtude deve ser prezada./ Se me isto o Ceo concede, e o vosso peito/ Dina empresa tomar de ser cantada/ - Como a presaga mente vaticina,/ Olhando a vossa inclinação divina -“

\section{Canto X, 156}

"Ou fazendo que mais que a de Medusa/ A vista vossa tema o monte Atlante,/ Ou rompendo nos campos de Ampelusa/ Os muros de Marrocos e Trudante;/ A minha já estimada e leda Musa/ Fico que em todo o mundo de vós cante/ De sorte que Alexandro em vós se veja/ Sem a dita de Achilles ter enveja."

O poeta finaliza o poema, pressagiando que, graças à inclinação divina que vê no Rei, sabe que este realizará grandes feitos e que estes serão tão valorosos quanto os de Alexandre, mas, diferentemente dos deste, que não tiveram quem os cantasse, os de Sebastião serão cantados por um grande poeta, como os de Aquiles foram por Homero, na Ilíada.

\footnotetext{
${ }^{42}$ Canto X, 155

Os três últimos versos: "Não se aprende, senhor, na phantasia,/ Sonhando, imaginado ou estudando,/ Senão vendo, tratando e pelejando"

43 “(...) Segundo Cícero (De Inventione, I, 16,22), é conveniente que o orador manifeste submissão e humildade", pag. 126 e logo adiante: "Concorreu a autoridade da Bíblia para que o antigo topos se combinasse frequentemente com fórmulas de auto-humilhação, oriundas do Velho Testamento", pag. 128. CURTIUS, Ernest Robert. Literatura Européia e Idade Média Latina. São Paulo, EDUSP, 1996. A tópica da modéstia associada aos preceitos cristãos é utilizada por Camões no trecho citado.
} 
Do gênero demonstrativo, o poema traz também inúmeras características. É fim do gênero épico louvar os feitos de homens superiores e é fim do gênero demonstrativo o elogio e o vitupério. As características que os aproximam serão aplicadas na análise do poema para tratarmos dos epítetos injuriosos que caracterizam os mouros. Para isto, as preceptivas de elogio e vitupério, presentes na Retórica ${ }^{44}$ de Aristóteles, na Retórica a Herênio $^{45}$, de autor anônimo, no Do Orador $^{46}$ de Cícero e nas Instituições Oratórias ${ }^{47}$ de Quintiliano, serão nossas guias.

Segundo Aristóteles, o fim para aqueles que elogiam é o belo e o feio, o virtuoso e o vicioso. Assim elucida o que entende por belo, bom e virtuoso:

Pois bem, o belo é o que, sendo preferível por si mesmo, é digno de louvor; ou o que, sendo bom, é agradável porque é bom. E se isto é belo, então a virtude é necessariamente bela, pois sendo boa, é digna de louvor. (...) Os elementos da virtude são a justiça, a coragem, a temperança, a magnificência, a magnanimidade, a liberalidade, a mansidão, a prudência, e a sabedoria. As maiores virtudes são necessariamente as que são mais úteis aos outros, posto que a virtude é a faculdade de fazer o bem. Por esta razão se honram, sobretudo, os justos e os corajosos; pois a virtude destes é útil aos demais na guerra, e a daqueles é útil também na paz. ${ }^{48}$

Elogia-se, pois as ações belas e virtuosas de homens que agiram por escolha ${ }^{49}$, e censura-se as ações vergonhosas e viciosas de homens que também assim agiram. $N^{\prime} O s$ Lusíadas são os Portugueses e seus feitos louvados e são os Mouros e seus feitos vituperados.

\footnotetext{
${ }^{44}$ ARISTÓTELES. Retórica. Lisboa: Imprensa Nacional - Casa da Moeda, 1998.

${ }^{45}$ Retórica a Herênio. São Paulo: Hedra, 2005. Foi por muito tempo atribuída a Cícero, mas hoje não se sabe quem foi realmente seu autor.

${ }^{46}$ Do Orador, Livro II, 45-46. In: SCATOLIN, Adriano. Tese de Doutorado sob orientação da Profa Dra Zélia L. V. de Alencar Cardoso. A Invenção no Do Orador de Cícero: um estudo á luz de Ad Familiares I, 9, 23. Faculdade de Filosofia, Letras e Ciências Humanas da Universidade de São Paulo, 2009.

${ }^{47}$ QUINTILIANO. Institution Oratoire, vol. 1 (Livres I-III) e 2 (Livres IV-VI). Paris: Librairie Garnier Frères, 1934. Traduzida do original latino.

${ }^{48}$ ARISTÓTELES. Retórica, pag. 74

49 Idem, pag. 77.
} 
Na Retórica a Herênio está exposto que o elogio pode ser das coisas externas, do corpo e do ânimo.

Como coisas externas entende-se aquelas que "podem acontecer por obra do acaso ou da fortuna, favorável ou adversa: ascendência, educação, riqueza, poder, glória, cidadania, amizades, enfim, coisas dessa ordem e seus contrários."

Do corpo elogia-se o que a natureza forneceu de vantajoso ou desvantajoso, como rapidez, força, beleza, saúde e para o vitupério, seus contrários.

Quanto ao ânimo, refere-se o texto às coisas que comportam nossa deliberação e reflexão: prudência, justiça, coragem, modéstia, e para o vitupério, seus contrários.

Sendo assim, preceitua o autor para o discurso demonstrativo: "Será necessário expor as virtudes ou vícios do ânimo e depois demonstrar de que modo foram tratadas por tal ânimo as vantagens ou desvantagens do corpo ou das circunstancias externas." ${ }^{\text {, }}$ N'Os Lusíadas, no entanto, são os mouros constantemente vituperados e os vícios identificados são, em sua maior parte, relativos ao ânimo e às circunstancias externas. Os vitupérios relativos ao corpo são quase inexistentes. Veremos detalhadamente tal aspecto adiante, na análise do poema.

Cícero em seu Do Orador $^{52}$, diz:

45. De fato, daquelas fontes de onde se tomam os preceitos para todos os ornamentos do discurso, será possível ornar também o louvor, e não faltarão aqueles elementos, pois, embora ninguém os ensine, quem é que não sabe o que deve ser elogiado num homem? De fato, estabelecido aquilo que Crasso disse no início daquele discurso que, como censor, pronunciou contra seu colega: no que a natureza ou a fortuna concederam aos homens, podia suportar tranqüilamente ser superado, naquilo que os próprios homens podem granjear para si, não podia suportar ser vencido; quem louvar alguém notará que deve tratar dos bens da fortuna; 46. tais são os de estirpe, dinheiro, parentes, amigos, recursos, saúde, beleza, forças, engenho e demais coisas que são do corpo ou externas; se os teve, que fez bom uso deles, se não os

\footnotetext{
${ }^{50}$ Retórica a Herênio. São Paulo: Hedra, 2005. Pag. 161.

${ }^{51}$ Idem, pag. 165.

52 Do Orador, Livro II, 45-46. In: SCATOLIN, Adriano. A Invenção no Do Orador de Cícero: um estudo á luz de Ad Familiares I, 9, 23. São Paulo, 2009.
} 
teve, que passou sem eles com sabedoria; se os perdeu, que o suportou com moderação; depois, o que aquele a quem se louvar fez ou suportou com justiça, grandeza, piedade, gratidão, humanidade, enfim, com alguma virtude. Aquele que quiser louvar perceberá facilmente esses pontos e os deste gênero; aquele que quiser vituperar, os seus contrários."

É mais digno de louvor, segundo percebe-se pelo trecho citado de Cícero e como já havia sido afirmado por Aristóteles ${ }^{53}$, o homem que age por escolha. Os bens fornecidos pela fortuna podem ser elogiados, mas é, sobretudo, "naquilo que os homens podem granjear para sim" que reside a possibilidades de elogios mais eloqüentes e grandiosos. É o bom uso que se faz dos bens fornecidos pela fortuna, mais que os próprios bens, que merece elogio. É se o homem agiu com sabedoria ou moderação se tais bens faltaram ou se perderam que é digno de louvor. Além disso, que virtudes demonstrou no decorrer dos acontecimentos de sua vida, se foi sábio, nobre, corajoso, justo etc. é o que se deve observar para se fazer o elogio; pois sendo a virtude fruto do hábito, o homem que a possui não a possui por acidente e sim por merecimento.

Por fim, há Quintiliano e suas Instituições Oratórias. Nestas o autor também preceitua sobre o elogio e o vitupério. Por ser posterior a todos os outros autores citados, Quintiliano compilou os ensinamentos dos seus antecessores e os colocou engenhosamente e, nas palavras de Barthes ${ }^{54}$, pedagogicamente, na sua completa e fundamental obra. Por isso, é a divisão estabelecida por Quintiliano que seguiremos, por ser ela abrangente e contemplar todas as preceptivas de elogio e vitupério até agora citadas.

Segundo Quintiliano, pode-se elogiar deuses, homens, seres animados e até mesmo inanimados. No que se refere ao elogio dos homens o discurso deve ser construído levando-se em consideração uma sequência de lugares, loci, que orietam e organizam a Inventio. Tais lugares estão descritos na Institutio Oratoria ${ }^{55}$, nos livros III e V, capítulos VII e X, respectivamente. São eles: família (genus), nação (natio), pátria (patria), sexo (sexus), idade (aetas), educação e instrução (educatio et disciplina),

\footnotetext{
${ }^{53}$ ARISTÓTELES. Retórica. Pag. 77.

${ }^{54}$ BARTHES, Roland. A Retórica Antiga. In: A Aventura Semiológica. São Paulo: Martins Fontes, 2001.

${ }^{55}$ QUINTILIANO.
} 
constituição física (habitus corporis), fortuna ou sorte (fortuna), condição social (condiciones), caracteres (animi natura), ocupação (studia quoque), aparência (quid affested), ações e palavras (ante acta dictaque), nome (nomen). ${ }^{56}$

Alguns destes lugares se confundem, podendo ser tratados conjuntamente. É o caso da educação e da condição. Nestes deve-se considerar o grau de instrução de uma pessoa, se ela pôde estudar ou não, se ela é civilizada ou não, se é pai ou filho, se é um homem ilustre ou desconhecido, o que revela a educação que recebeu e a condição que tem. Igualmente tais informações dizem respeito à fortuna, pois esta determina se um homem é pobre ou rico, se tem amigos ou não etc. Outro exemplo se refere ao lugar de nação e de pátria. Por vezes esses dois lugares se confundem. Para a análise d'Os Lusíadas não serão considerados todos os lugares, pois nem todos foram utilizados pelo poeta. Os lugares de família, nação, pátria, educação e instrução, caracteres e ações e palavras serão os abordados, devido ao fato de os elogios e os vitupérios estarem em sua maior parte inseridos neles.

Sendo, pois, Os Lusíadas nosso objeto de análise, a partir de agora sobre este nos deteremos, a fim de compreender a caracterização do Mouro no épico, tendo em vista sua condição de inimigo da fé e do império português.

\section{a) Lugar de Família}

pois se crê que geralmente os filhos se assemelham a seus pais e a seus ancestrais, semelhanças que por vezes influenciam sua vida, fazendo com que ela seja honesta ou desonesta ${ }^{57}$

Ou seja, se os pais foram viciosos, os filhos podem vir a sê-lo. E se os pais foram virtuosos, provavelmente também o serão os filhos.

Duarte Galvão, ao descrever a ascendência de Afonso Henriques destaca sua origem nobre:

\footnotetext{
56 QUINTILIANO. Institution Oratoire, vol. 2, pag. 165 e LAUSBERG, Heinrich. Manual de Retórica Literária. Madrid: Editorial Gredos, S.A., 1966. Pag. 317.

57 "genus, nam similes parentibus ac majoribus filii plerumque creduntur, et nonnumquam ad honeste turpiterque vivendum inde causae fluunt" Institution Oratoire, V- X, pag. 162. São nossas as traduções.
} 
"Este Rey dom Affonso Hanriques, primeiro Rey que foy de Portugall, era neto del Rey d'Umgria da parte do Comde dom Hamrrique seu pay, que era filho lidemo del Rey d'Umgria. E da parte de sua may era neto del Rey dom Affomsso de Castela acima dito, filho de sua filha dona Tareyja" ${ }^{\text {"58 }}$

Afonso Henriques tem, pois uma origem nobre e, por isso, o título que recebe de rei de Portugal é merecido, pelos valorosos feitos que realiza, ${ }^{59}$ e justo, devido a seu elevado nascimento.

N'Os Lusíadas são os mouros descendentes de uma escrava, origem esta baixa, indigna, vergonhosa.

\section{Canto I, 53}

"Somos, hum dos das Ilhas lhe tornou,/ Estrangeiros na terra, Lei e nação, /Que os próprios, Sam aquelles que criou/ A Natura sem Lei e sem Razão:/ Nos temos a Lei certa que insinou,/ O claro descendente de Abrahão:/ Que agora tem do Mundo o senhorio,/ A mãy Hebrea teve, e o pay Gentio"

Assim descreve seu povo um dos habitantes de Moçambique à Vasco da Gama. Ele revela a ascendência do fundador da Lei que segue, Maomé. A origem narrada por Camões é semelhante à descrita por Covarrubias em seu dicionário:

Mahoma: (que nunca hubiera nacido em el mundo) nació em Arabia, em el lugar llamado Zatrarip, que está cerca de Meca; fue hijo de Abdalá y de Emina, su mujer, hija de Ayop y descendiente de Ismael, hijo de Abraham e de Agar, su esclava. (...) En cuanto a la etimologia, todos concuerdam ser hebreo o traer origen de allá, y vale tanto como colocado. Dios, cuando fuere servido y conviniere, le derrocará ${ }^{60}$.

\footnotetext{
${ }^{58}$ GALVÃO, Duarte. Crônica de El-Rei Afonso Henriques.

${ }^{59}$ Narrados por Duarte Galvão em sua crônica e por Camões n'Os Lusíadas.

${ }^{60}$ OROZCO, Sebastián de Covarrubias. Tesoro de la Lengua Castellana o Espanola. (1611). Madrid: Editorial Castalia, 1995.
} 
Ambos reconhecem ser Maomé descendente de Ismael, portanto de Abraão. Interessante notar que, no dicionário, o autor valora sua definição e repudia a informação que fornece. Nos versos do poema não há vitupério ainda, mas este não tardará em aparecer.

\section{Canto III, 26}

"Este despois que contra os descendentes,/ Da escrava Agar, victorias grandes teve,/ Ganhando muitas terras adjacentes,/ Fazendo o que a seu forte peito deve./ Em prêmio destes feitos excellentes,/ Deulhe o supremo Deos, em tempo breve,/ Hum filho, que illustrasse o nome ufano/ Do belicoso Reino Lusitano"

Os versos referem-se a Henrique, que ganhou o Condado Portucalense, futuro reino de Portugal, como dote pelas lutas que tivera contra os "descendentes da escrava Agar".

Agar era uma escrava egípcia pertencente a Sara, esposa de Abraão. Não podendo esta engravidar e gerar um herdeiro para Abraão, Sara pediu que seu marido se deitasse com Agar, a fim de garantir sua descendência. Agar engravidou e deu a luz a um filho. Esse filho foi Ismael ${ }^{61}$, cujo destino foi profetizado, antes de seu nascimento, a Agar por um anjo de Javé: "Eu farei a descendência de você tão numerosa que ninguém poderá contar (...). Você está grávida e vai dar à luz um filho e lhe dará o nome de Ismael, porque Javé ouviu sua aflição. Ele será potro selvagem: estará contra todos, e todos estarão contra ele; e viverá separado de seus irmãos". É Ismael o ancestral dos árabes.

Maomé, segundo a tradição árabo-judaica é descendente de Ismael, sendo, também, portanto, descendente de uma escrava; o que torna sua origem baixa e o desqualifica.

Nos versos acima, destaca-se também a derrota que sofreram os maometanos nas lutas contra Henrique, que deles ganhou "muitas terras adjacentes". Tais lutas, "feitos excellentes" agradaram a Deus que em breve tempo deu-lhe um filho como prêmio. A luta contra os maometanos era, portanto, uma luta que agradava a Deus. Se o que agrada

\footnotetext{
${ }^{61}$ Gênesis, 16.
} 
a Deus é a vida virtuosa, como foi dito por São Tomás, a luta contra o mouro agrada enormemente a Deus, pois a defesa da fé cristã era a máxima virtude.

Canto III, 110

“Estão de Agar os netos casi rindo,/ Do poder dos Christãos fraco e pequeno,/ As terras como suas repartindo,/ Antemão entre o exército Agareno,/ Que, com título falso possuindo/ Está o famoso nome Sarraceno;/ Assi também, com falsa conta e nua,/ à nobre terra alheia chamam sua"

Os que adotaram a Lei de Maomé são também descendentes, netos, da escrava Agar. É mais uma vez referida a ascendência baixa dos maometanos. Os versos citados fazem parte da narração da Batalha de Salado. Desta falaremos mais detalhadamente quando tratarmos do lugar dos Caracteres. Quanto ao termo "Sarracenos", falaremos dele quando tratarmos do lugar Pátria.

Canto VIII, 47

"A isto mais se ajunta que um devoto/ Sacerdote da Lei de Mafamede,/ Dos ódios concebidos não remoto/ Contra a divina Fé, que todo excede./ Em forma do Propheta falso e noto,/ Que do filho da escrava Agar procede,/Baco odioso em sonhos lhe aparece,/ Que se seus ódios inda se não deçe”

Mais uma vez, é Maomé, "Propheta falso e noto", referido como descendente de Agar. Note-se que apenas uma vez, Abraão é mencionado (Canto I, 53). O elo que liga as religiões monoteístas é praticamente ignorado. O que se pretende enfatizar é a ascendência baixa e vergonhosa dos mouros, por parte de Agar.

Segundo Quintiliano, para se elogiar ou vituperar uma pessoa, observar sua ascendência é importante. Será digna de elogio, se sua ascendência for elevada, nobre; e de vitupério, se for baixa, humilde. Pois se espera que de uma alta estirpe, se originem boas obras e de uma baixa, más obras.

João de Barros reafirma essa máxima ao escrever sobre a ascendência do infante Dom Anrique: "E como da excellecia do sangue pola mayor parte procede todas 
inclinações da pessoa: podemos crer, que sobreste fundamento, deos edificou nelle as outras dálma q em quãto viveo mostrou em suas obras."62

Blas Verdu também compartilha essa opinião. Ele afirma que por serem descendentes de escravos, os agarenos são inclinados ao mal; são traidores, mentirosos, invejosos e baixos ${ }^{63}$.

No entanto, para Quintiliano, grandes feitos poderiam anular uma baixa extração ${ }^{64}$ : “(...) por seus altos feitos, ele destaca uma origem mais humilde”. Os mouros, apesar de descenderem de uma escrava, poderiam se altos feitos realizassem, se dignificarem. No entanto, longe de os praticarem, seguem a um "Propheta falso e noto"; o que os torna alvos do vitupério dos cristãos.

\section{b) Lugar de Nação}

pois as diferentes nações possuem modos próprios, e uma coisa não é a mesma para um bárbaro, um Romano, um Grego ${ }^{65}$.

No dicionário de Bluteau, assim é definido o termo "Nação":

Nome collectivo, que se diz da gente que vive em alguma grande região, ou Reyno, debaixo do mesmo Senhorio. Nisto se differença nação de povo, porque nação comprehende muitos povos, e assim Beirões, Minhotos, Alentejões, etc compõem a nação Portugueza; Bávaros, Saxões, Suabos, Abruguezes, Brabdeburguezes, etc compõem a nação Alemãa/ Castelhanos, Aragonezes, Andaluzes, etc compõem a nação Hespanhola ${ }^{66}$.

\footnotetext{
${ }^{62}$ BARROS, João de. Ásia. Primeira Década. Coimbra: Imprensa Nacional-Casa da Moeda, 1932. Pag. 60.

${ }^{63}$ Frei espanhol, autor do livro: Enganos y Deseganos del Tiempo. Con un discurso de la expulsions de los Moriscos de Espana (1612). Citado por CARDAILLAC, Louis. Moriscos y Cristianos: un enfrentamiento polémico (1492-1640). México, FCE, 2004

64 “(...) aut humilius genus illustrasse factis”. QUINTILIANO. Institution Oratoire I, pag. 375.

65 "natio, nam et gentibus proprii mores sunt nec idem in bárbaro, Romano, Graeco probabile est" QUINTILIANO. Intitution Oratoire, $\mathrm{V}-\mathrm{X}$.

${ }^{66}$ Bluteau, Raphael. Vocabulario Portuguez e Latino, aulico, anatomico, architectonico... Coimbra: No Collegio das Artes da Companhia de Jesu, 1712.
} 
Concordamos com essa definição e acreditamos que ela contempla o que Quintiliano quis elucidar quando cita os bárbaros, os romanos e os gregos. São os portugueses, os espanhóis, os marroquinos, os mauritanos, os alemães, os franceses componentes de suas respectivas nações.

N'Os Lusíadas há referências a uma série de nações. Em relação aos termos "mouros", "mauros" e "sarracenos", embora designem, originalmente os habitantes de nações específicas, o poeta os utiliza para nomear, na maioria das vezes, os maometanos. O vitupério que estes recebem é devido à religião que professam, raramente devido à nação a que pertencem. Vejamos separadamente:

\section{b.1) Mouros e Mauros}

Antonio Farinha afirma que o termo "mouros" foi a designação mais freqüente adotada pelos cristãos para se referirem aos invasores que atravessaram o estreito de Gibraltar para se instalarem na Ibéria, termo este já utilizado pelos romanos para a população no norte da África ${ }^{67}$.

Sendo assim, "Mouro", "maura gente", "mauritano", "mauro hispano", referemse, a princípio, aos povos que vieram da região da Mauritânia, no norte da África ${ }^{68}$.

No entanto, com o passar do tempo, tais termos, sobretudo "mouro" passou a designar todos os maometanos, numa vasta generalização ${ }^{69}$. No poema, os mouros aparecem nos mais variados contextos, independentemente de terem nascido na Mauritânia ou não.

Aparecem em África: Canto I, 61

\footnotetext{
${ }^{67}$ FARINHA, Antônio Dias. Os árabes nos antigos relatos portugueses do Indico. Finisterra, XL, 79, 2005, pags. 151-160. Disponível em: http://www.ceg.ul.pt/finisterra/numeros/2005-79/79_12.pdf

${ }^{68}$ Etimologicamente, a origem do termo é grego: "Isidore de Sévilhe (VI siècle après J.C.) rapporte que les Maures étaient ainsi appelés par les Grecs à cause de leur couleur, car chez les Grecs, dit il, $\mu \alpha \delta \rho \circ \varsigma$ signifiait noir." BLOCH, Adolphe. Etymologie et définitions diverses du nom de Maure. In: Bulletins et Mémoires de la Société d'anthropologie de Paris, $V^{\circ}$ Série. Tome 4, 1903. pp. 624-628. Disponível em: http:// www.persee.br.

69 “Na Litteratura portuguesa antiga, tanto erudita quanto popular, o vocábulo <<Mouro>> é empregado freqüentemente não como nome éthnico, mas para designar aquelle que segue a religião mahometana, por ex.: hum Mouro Persiano (Lucena X)" Comentário de Epiphanio Dias in: Os Lusíadas.
} 
"Recebe o Capitão alegremente,/ O Mouro, e toda sua companhia,/ Dá-lhe de ricas peças um presente/ Que só pera este efeito já trazia;/ Dá-lhe conserva doce e dálhe o ardente/ Não usado licor, que dá alegria./ Tudo o Mouro contente bem recebe,/ E muito mais contente come e bebe."

Vasco da Gama, em Moçambique, recebe a bordo os habitantes da Ilha, a fim de travar amizade. São mouros e são maometanos, pois seguem a "Lei certa que insinou/ o claro descendente de Abrahão" (Canto I, 53). É o primeiro local onde o poeta faz com que aporte a frota de Gama. O poeta mostra conhecimento dos preceitos do Islã ao dizer "Não usado licor". Realmente o consumo de álcool é vedado aos maometanos. No entanto, o "Regedor da Ilhas" o aceita e o bebe. Por infringir uma lei, é o Mouro vicioso, mesmo sendo a regra de uma "errada Seita" (Canto I, 57).

Em Quiloa também ser mouro é ser maometano: Canto I, 99

"Ho mesmo o falso Mouro determina/ Que o seguro Christão lhe manda e pede;/ Que a Ilha he possuida da malina/ Gente, que segue o torpe Mahamede/ Aqui o engano e morte lhe imagina/ Porque em poder e forças muito excede/ à Moçambique esta Ilha, que se chama/ Quiloa, mui conhecida pola fama”

Quiloa é uma ilha habitada por mouros, seguidores do "torpe Mahamede". Os epítetos injuriosos de que Maomé é alvo serão analisados posteriormente, quando tratarmos do lugar dos Caracteres. Nos versos acima podemos notar que são os mouros "malinos" e "traiçoeiros", pois planejam dar a Gama um falso piloto para o conduzir às Índias. O referido episódio será novamente abordado também no lugar dos Caracteres.

Os mouros aparecem também em terras de Portugal: Canto I, 25

"Já lhe foy (bem o vistes) concedido,/ Cum poder tam singelo e tam pequeno,/ Tomar ao Mouro forte e guarnecido,/ Toda a terra que rega o Tejo ameno:/ Pois contra o Castelhano tão temido/ Sempre alcançou favor no Céu sereno./ Assi que sempre, enfim, com fama e glória/ Teve os troféus pendentes da vitória "

O narrador se refere às chamadas guerras de Reconquista, nas quais os portugueses retomaram as terras que estavam sob domínio de mouros. Seu principal representante foi Afonso Henriques, primeiro rei de Portugal, que, após a Batalha de 
Ourique, tornou-se lendário. "Mouro forte e guarnecido" refere-se, pois, aos mouros habitantes de Portugal. Da mesma forma nos versos seguintes:

Canto III, 42

"Mas já o Príncipe Affonso aparelhava/ O Lusitano exército ditoso,/ Contra o Mouro que as terras habitava/ Dalem do claro Tejo deleitoso:/ La no campo de Ourique se assentava,/ O arraial soberbo e belicoso,/ Defronte do inimigo Sarraceno,/ Posto que em força, e gente tam pequeno"

Esses versos fazem parte da narração de Vasco da Gama ao rei de Melinde, após este ter lhe pedido que contasse sobre as guerras havidas entre os cristãos e o povo que "a Mafoma adora" (Canto II, 108). Trata-se da Batalha de Ourique, que trataremos quando abordarmos o lugar dos Caracteres.

Os Mouros aparecem no poema também em Espanha: Canto III, 112

“Desta arte o Mouro perfido despreza,/ O poder dos Christãos, e não entende,/ Que está ajudado da alta fortaleza/ A quem o Inferno horrífico se rende/ Co ela o Castelhano, e com destreza,/ De Marrocos o Rei comete e ofende;/ O Português, que tudo estima em nada,/ Se faz temer ao Reino de Granada"

Nos versos acima há referências a vários povos e nações: "Castelhano", "Português", Marrocos, Granada. E o Mouro, de onde é? Não se pode afirmar. O que se pode afirmar é que o termo se refere aos maometanos, que estão se opondo aos cristãos e que não estão como estes sendo ajudados da "alta fortaleza/ A quem o Inferno horrífico se rende". É o "Mouro" o adversário.

Os versos fazem referência à Batalha de Salado, que será retomada quando abordarmos o lugar dos Caracteres.

\section{Canto III, 115}

"Já se ia o Sol ardente recolhendo/ Pera a casa de Tethys, e inclinado/ Pera o Ponente, o véspero trazendo,/ Estava o claro dia memorado,/ Quando o poder do Mouro, grande e horrendo,/ Foi pelos fortes Reis desbaratado,/ Com tanta mortindade, que a memória/ Nunca no mundo viu tão grão vitória" 
Assim se encerra a narração da Batalha de Salado, vencida pelos cristãos, após difícil e sangrenta batalha.

No poema, há mouros também na Índia: Canto VIII, 48

"E diz-lhe assi: <<Guardai-vos, gente minha,/ Do mal que se aparelha pelo immigo/ Que pelas águas húmidas caminha,/ Antes que esteis mais perto do perigo>>. Isto dizendo acorda o Mouro asinha/ Espantado do sonho: mas consigo/ Cuida que não he mais que sonho usado./ Torna a dormir, quieto e sossegado"

$\mathrm{Na}$ Índia, Baco aparece em sonho a um mouro importante conhecido do Samorim, governante de Calecute, e lhe induz contra os portugueses. O mouro vai até o Samorim e lhe conta o que sonhou.

\section{Canto VIII, 58}

"Fallar ao Rei Gentio determina,/ Porque com seu despacho se tornasse/ Que já sentia em tudo da malina/ Gente impedirse quanto desejasse:/ O Rei que da notícia falsa, e indina/ Nam era despantar se sespantasse,/ Que tam crédulo era em seus agouros,/ E mais sendo affirmados pelos Mouros"

O rei de Calecute acredita no que é dito pelos mouros, contra os portugueses. Mas as intrigas armadas pelos mouros serão analisadas quando tratarmos do lugar dos Caracteres.

Os versos citados acima exemplificam a ocorrência do termo "mouro" em várias nações, independentemente de as pessoas a quem ele nomeia serem da Mauritânia ou não.

Nas crônicas consultadas, de Duarte Galvão, Rui de Pina e de João de Barros há predominância da palavra "Mouro" em relação a todas as outras designações.

N'Os Lusíadas, o termo "Mauro" e correlatos também ocorrem com freqüência:

Canto I, 6: "Vos o novo temor da Maura lança,". Canto I, 76: "Eu decerey aa terra, e o indignado/ Peito, revolverey da Maura gente". Canto I, 93: "Ficava a Maura gente magoada,/ No ódio antigo, mais que nunca acesa". Canto II, 25: "O grande estrondo, a Maura gente espanta". Canto II, 68: "Porque avião de ser da Maura gente". Canto III, 20: "Este quis o Ceo justo, que floreça/ Nas armas, contra o torpe 
Mauritano;/ Deitando o de si fora". Canto III, 53: "Desbaratado e roto o Mauro Hispano". Canto III, 75: "Avante passa, e faz correr vermelho,/ O rio que Sevilha vay regando,/ Co sangue mauro, barbaro e nefando". Canto III, 77: “Ao som da Mauritana e ronca tuba". Canto VI, 83: "O ditosos aquelles que puderão/ Entre as agudas lanças Affricanas/ Morrer, em quanto fortes sostiverão/ A sancta Fe, nas terras Mauritanas”. Canto VII, 77: "Alçase em pé, co elle os Gamas junto/ Coelho de outra parte, e o Mauritano"etc..

Dentre todos os versos citados, apenas o último refere-se a uma pessoa de origem comprovadamente mauritana. Monçaide, intérprete que Gama encontrou em Calecute, diz ter vindo da região da Berbéria e sido educado da Lei de Maomé pelos seus parentes. Nas outras citações, percebemos que a palavra em destaque poderia ser trocada por "mouro" ou "sarraceno", ou alguma outra generalização, pois o efeito semântico que traria seria o mesmo: o efeito que se pretende é destacar que são maometanos, que não são cristãos e que, portanto, a animosidade contra eles é justificada. Se suas nações são vituperadas não é devido a outro motivo que não o de seus habitantes seguirem a Lei de Maomé.

\section{b.2) Sarracenos}

Origem mais incerta tem o termo "Sarraceno". A primeira vez que ele ocorre no poema é no Canto III, 23:

"Hum Rei, por nome Affonso, foy na Espanha,/ Que fez aos Sarracenos tanta guerra/ Que por armas sanguinas, força e manha/ A muitos fez perder a vida, e a terra./ Voando deste Rei a fama estranha/ Do Herculano Calpe à Cáspia Serra,/ Muitos pera na guerra esclarecer-se,/ Vinham a ele e à morte oferecer-se"”.

O termo aparece pela segunda vez no Canto III, 110 e Vasco da Gama, que é quem tem a palavra desse momento do poema, nos explica sua origem:

Canto III, 110

"Estão de Agar os netos casi rindo,/ Do poder dos Christãos, fraco e pequeno,/ As terras como suas repartindo,/ Ante mão, entre o exército Agareno:/ Que com título 
falso possuindo/ Esta o famoso nome Sarraceno./ Assi tambem com falsa conta e nua,/ Aa nobre terra alheia chamão sua"

Segundo Bluteau, "Sarraceno" é o nome dado antigamente aos mouros. Assim ele define em seu dicionário, o primeiro de Língua Portuguesa, publicado no início do século XVIII.

SARRACENO. He o nome que antigamente se deu aos que hoje chamamos Mouros. Deriva do arábico essanac, que val o mesmo que Robadores ou Salteadores. Também forão chamados Agarenos e Ismaelitas, como descendentes de Agar, mãy de Ismael, posto que na opinião de alguns descendem de Cam. Também se chamão Sarracenos, nome que lho deu Mafoma, porque se prezava de descender da casta de Sara, mulher legítima de Abraham, não sendo senão de Agar sua escrava, e de gente Ismaelita e reprovada. ${ }^{70}$

Blas Verdu, em sua obra de 1612 "Engaños y Desengaños del Tiempo", afirma que os adeptos do Islã não merecem tal nome, pois não descendem de Sara, mas sim de Agar, por isso, o único nome que lhes é próprio é o de Agarenos ${ }^{71}$.

De tal opinião compartilha Aznar Cardona, também no século XVII: "Sarracinos o sarracenos, nombre que se tomaram por honrarse, deviendo ser llamados agarenos por la madre Agar o ismaelitas por su padre Ismael, o Arabes, o Alarbes, por la tierra donde tomaran naturaleza, dicha Arabia.,72

Segundo Domingos ${ }^{73}$, a idéia de "Sarraceno" derivar de Sara é muito remota. Diz-nos que encontramo-la pela primeira vez em São Jerônimo, no seu comentário a Ezequiel. Também está presente em Isidoro de Sevilha, em seu Etimologias $^{74}$, e

\footnotetext{
${ }^{70}$ BLUTEAU, Raphael. Vocabulario Portuguez e Latino, aulico, anatomico, architectonico... Coimbra, 1712-1728. Disponível em: http://www.ieb.usp.br/online/dicionarios/bluteau/formBuscaDicionarioPIChave.asp

${ }^{71}$ Citado por CARDAILLAC, Louis. Moriscos y Cristianos: un enfrentamiento polémico (1492-1640). México: FCE, 2004.

72 Citado por IBARRA, Miguel Angel de Bunes. Los Moriscos em el pensamiento histórico. Madrid: Ediciones Cátedra, S.A., 1983.

73 DOMINGUES, José D. Garcia Domingues. A Concepção do Mundo Árabe-Islâmico n'Os Lusíadas. In: Garcia De Orta. Revista da Junta de Investigações do Ultramar. Lisboa, número especial 1-608, 1972.

74 “Isidore donne ailleurs une entrée plus complète pour <<Sarrasins >>: <<Les Sarrasins (Saraceni) ainsi nommés soit parce qu'ils se prétend descendants de Sara, soit, au dire dês paiens, parce qu'ils sont d'origine syrienne, comme Syrigènes (Syriginae). Ils habitent um três vaste désert. On les appelle aussi Ismáelites, selon l'enseignement Du livre de la Genèse, parce qu'ils sont issus d'Ismael. Ou encore Agaréniens (Agareni) d'après Agar. Ce sont eux, comme nous l'avons dit, que l'on appelle à tort
} 
percorre um longo caminho, passando por Camões, que a repete, e chegando ao século XVIII, como vimos em Bluteau ${ }^{75}$.

No entanto, há autores que tentaram dar uma outra explicação para o origem da palavra "Sarraceno". Bleda foi um deles. Em seu tratado apologético "Defensio Fidei" ele diz: "Si a Sara nominarentur Sarani et non Saraceni essendi dicendi",76 . Outro foi um autor anônimo do século XIII, que afirmou serem os sarracenos oriundos da região de Sarras, uma vila situada entre a Babilônia e Samarcanda, devendo a isso seu nome. Afirma também que os sarracenos, antes pagãos, se converteram à seita de Maomé, assim que esta surgiu. ${ }^{77}$

Há versões também que corroboram a tese de a palavra ter se originado do termo árabe Essanac, que significa "roubadores" ou "salteadores", considerada também, como vimos, por Bluteau ${ }^{78}$; ou de Sharkiah, que significa "Orientais "79", e que, devido a uma adaptação fonológica na transcrição, originou "sarracenos".

Percebemos, no entanto que "sarraceno", na maioria dos textos estudados, deriva de Sara; daí a falsidade do nome resultando em outras falsidades: Falso o nome, falso o direito à terra, falsa a gente. E, da mesma maneira que o termo "mouro", aparece no poema para se referir aos maometanos de Portugal, da Espanha ou da Índia.

\footnotetext{
Sarrasins, parce qu'ils se vantent de descendre de Sara>> (Etymologies, IX, 2, 57)" In: TOLAN, John. Les Sarrasins. pag. 379.

${ }^{75}$ Covarrubias, em seu Tesoro de la Lengua Castellana o Espanola (1611), assim define Sarracenos: Se dicen los moros [sic: decender o descender] de Sarra, mujer del patriarca Abraham; lo más cierto es ser decendientes de su sierva Agar, aunque por adopción se pudo llamar Ismael, hijo suyo, como consta del cap. 16 del Génesis, que Sarra dice a su marido Abraham: "Ecce conclusit me Dominus, ne parerem; ingredere ad ancillam mean, si forte saltem ex illa suscipiam filios". Josefo Scalígero, lib. 2, De emendatione temporum, dice que los principales apellidos de los árabes son dos: agarenos y sarracenos se dicen em arábico essarak, que quiere decir robadores o salteadores, éstos son nômades que no tienem habitación cierta". OROZCO, Sebastián de Covarrubias. Tesoro de la Lengua Castellana o Espanola. (1611). Madrid, Editorial Castalia, 1995.

${ }^{76}$ Citado por Louis Cardaillac. Moriscos y Cristianos.

${ }^{77}$ John Tolan. Les Sarrasins.

${ }^{78}$ E também por Covarrubias. Ver nota 41.

79 “Les dictionnaires etymologiques persistent à voir dans ce nom, issu d'um terme latin (saraceni). voire grec. une origine árabe: sharqiyin, les <<orientaux〉> (de Sharq, orient)". POUILLON, François. Simplification ethnique em Afrique Du Nord: Maures, Arabes, Berbères (XVIIle-XXe siècles). in: Cahiers d'études africaines. Vol. 33 № 129. Mesurer la différence: I'anthropologie physique. PP. 37-49. Disponível em: http://www.persee.fr
} 


\section{b.3) Turcos}

\section{Canto I, 64}

"Responde o valeroso Capitão,/ Por hum que a lingoa escura bem sabia./ Darte ey Senhor illustre relação/ De my, da ley, das armas que trazia/ Nem sou da terra, nem da geraçam,/ Das gentes enojosas de Turquia:/ Mas sou da forte Europa belicosa,/ Busco as terras da Índia tão famosa."

Vasco da Gama se apresenta ao "Regedor" de Moçambique e diz não ser da terra nem da geração das "gentes enojosas de Turquia". Por serem maometanos, são os Turcos repugnantes. É possível que as animosidades políticas sejam também responsáveis pelo vitupério aos turcos. No entanto, querendo o poeta destacar o caráter missionário da expansão marítima portuguesa, é verossímil que ele oculte o que não lhe parece relevante e destaque o que lhe parece mais importante.

\section{Canto II, 46}

"Fortalezas, Cidades, e altos muros,/ Por elles vereis filha edificados:/ Os Turcos belacíssimos e duros,/ Delles sempre vereis desbaratados./ Os Reis da Índia livres, e seguros,/ Vereis ao Rei potente sojugados./ E por elles de tudo em fim senhores,/ Serão dadas na Terra leis milhores"

Na estância anteriormente analisada, Vasco da Gama se apresenta como vindo da "Europa belicosa", virtude esta que dignifica sua terra, por significar ser ela destemida e confiante. Já nesta estância, são os "Turcos belacíssimos e duros". São palavras proferidas por Zeus à Vênus, predizendo os feitos que serão realizados pelos portugueses. O deus pagão prevê que os portugueses desbaratarão os "Turcos belacíssimos e duros" estando estes dois epítetos no sentido de "inconseqüentes" para "belacíssimos" e "teimosos" para "duros.

No Retórica a Herênio ${ }^{80}$ o autor afirma que é possível fazer com que uma aparente virtude seja tratada como vício, se este for a objetivo do orador. Se o termo "belicosa" é elogioso quando se refere à Europa; o termo "belacíssimo" é vituperante, quando referente à Turcos. O primeiro destaca a coragem dos europeus, ao passo que o segundo destaca a temeridade dos turcos.

\footnotetext{
${ }^{80}$ Retórica a Herênio, pag. 157.
} 


\section{b.4) Africanos}

Canto IV, 48

"Não sofre o peito forte usado aa guerra/ Não ter imigo já a quem faça dano,/ E assi não tendo a quem vencer na terra/ Vay cometer as ondas do Occeano:/ Este he o primeiro Rey que se desterra/ Da patria, por fazer que o Africano,/ Conheça pollas armas, quanto excede/ A lei de Christo aa ley de Mafamede"

\section{Canto VI, 83}

“O ditosos aquelles que puderão/ Entre as agudas lanças Affricanas/ Morrer, em quanto fortes sostiverão/ A sancta Fe, nas terras Mauritanas:/ De quem feitos illustres se souberão,/ De quem ficão memórias soberanas,/ De quem se ganha a vida com perdella,/ Doce fazendo a morte as honras della”

\section{Canto I, 2}

"E também as memorias gloriosas/ Daquelles Reis, que forão dilatando/ A Fee, o Imperio, e as terras viciosas/ De Affrica, e de Ásia, andarão devastando/ E aquelles que por obras valerosas/ Se vão da ley da Morte libertando./ Cantando espalharey por toda parte/ Se a tanto me ajudar o engenho e arte."

Nas três estâncias citadas o termo "Africano" se refere aos povos que serão conquistados, subjugados e, principalmente convertidos, pelos portugueses. É a África a terra de povos bárbaros, rústicos que precisam do convencimento feito pelas armas e, como os da Ásia, são viciosos. Faltam a eles virtudes, especialmente a virtude de ser cristãos. Suas terras viciosas foram devastadas pelos portugueses e estes, no lugar, puseram a virtude cristã, elevando a terra e sua gente.

\section{b.5) Outros Povos}

Não são somente os mouros, os mauritanos, sarracenos, turcos e africanos os povos vituperados no poema. Há outros, embora sejam vituperados por motivos diversos e de modo menos ofensivo. 


\section{Canto VII, 4}

Vedelos Alemães, soberbo gado,/ Que por tam largos campos se apacenta,/ Do successor de Pedro rebelado,/ Novo pastor, e nova ceita inventa/ Vedelo em feas guerras occupado,/ Que inda co cego error se nam contenta,/ Não contra o superbíssimo Otomano:/ Mas por sair do jugo soberano"

Os alemães são soberbos e a soberba é um vício, sendo a humildade a virtude que se lhe opõe. Refere-se o poeta à Reforma protestante, iniciada por Lutero e que originou uma "nova ceita". Ao invés de lutar contra o Otomano, luta justa por ser contra os maometanos, se rebelam contra o "jugo soberano" do Papa. Pecam os alemães pela soberba e pela desobediência.

\section{Canto VII, 5}

"Vedelo duro Ingles, que se nomea/ Rei da velha e sanctissima cidade,/ Que o torpe Ismaelita senhorea,/ (Quem vio honra tam longe da verdade)/ Entre as Boreais neves se recrea,/ Nova maneira faz de Christandade,/ Pera os de Christo tem a espada nua,/ Nam por tomar a terra que era sua"

O Inglês que se nomeia rei de Jerusalém é Henrique VIII. Estava a "sanctissima cidade", naquele momento, sob domínio dos maometanos "torpe Ismaelita"; ao invés de lutarem contra estes, "Nova maneira faz de Christandade" fundando a Anglicanismo.

\section{Canto VII, 6}

"Guardalhe por entanto hum falso Rei,/ A cidade Hierosolima terrestre,/Em quanto elle não guarda a sancta lei,/ Da cidade Hierosolima celeste:/ Pois de ti Gallo indigno que direy?/ Que o nome Christianissimo quiseste,/ Nam pera defendelo, nem guardalo,/ Mas pera ser contra elle, e derribalo"

\section{Canto VII, 7}

"Achas que tes direito em senhorios/ De Christãos, sendo o teu tam largo e tãto,/ E nam contra o Cynifio e Nilo rios/ Inimigos do antigo nome sancto,/ Ali se ande provar da espada os fios,/ Em quem quer reprovar da Ygreja o canto,/ De Carlos, de Luis, o nome e a terra/ Erdaste, e as causas nam da justa guerra?" 
As estâncias 6 e 7 referem-se aos franceses, que ao invés de lutarem contra os inimigos do "antigo nome sancto" se dedicam a coisas outras que não à guerra santa ou seja, à guerra contra os maometanos.

Canto VII, 8

"Pois que direy daquelles que em delicias,/ Que o vil ócio no mundo traz consigo,/ Gastão as vidas, logrão as divicias,/ Esquecidos de seu valor antigo:/ Nascem da tyrania inimicicias,/ Que o povo forte tem de si inimigo,/ Contigo Italia fallo, já sumersa/ Em vicios mil, e de ti mesma adversa."

São os italianos também alvo da repreensão do poeta, pois de dedicam a ócios e vícios ao invés de se dedicarem a causas mais devotas. Esquecem-se de seu valor antigo, dos feitos de seus antepassados e não lhes segue o exemplo. São, junto aos outros cristãos, causa dos lamentos do poeta.

\section{Canto VII, 9}

"O míseros Christãos, pola ventura/ Sois os dentes de Cadmo desparzidos,/ Que hus aos outros se dão aa morte dura,/ Sendo todos de hum ventre produzidos?/ Nam vedes a divina sepultura/ Possuida de cães, que sempre unidos/Vos vem tomar a vossa antiga terra,/ Fazendo se famosos pela guerra?"

Jerusalém está sob domínio dos maometanos, a quem o poeta chama de "cães", ofensivo e feroz vitupério. E se os cristãos repreendidos acima não se unirem para defenderem a Fé comum a todos, Portugal sozinha o fará. O vitupério aos seus "irmãos" contrapõe-se ao elogio à nação portuguesa, que se destaca como "Alferes da Fé." ${ }^{, 81} \mathrm{E}$ além da dilatação da Fé, têm os portugueses o dever de socorrer os indefesos, pois é justo, portanto virtuoso, apiedar-se dos inocentes e dos suplicantes.

\section{Canto VII, 13}

“Gregos, Traces, Armênios, Georgianos/ Bradando vos estão o povo bruto/ Lhe obriga os caros filhos aos profanos/ Preceptos do Alcorão (duro tributo!)”

\footnotetext{
81 “O poeta empresta o timbre mais belo da sua voz à emoção com que os seus contemporâneos viviam o espírito da catolicidade. Sentimo-lo, na primeira metade do século, em Garcia de Resende, tanto como em Gil Vicente, que chamava a Portugal o Alferes da Fé. Na segunda metade, é Camões que lhe dá expressão mais eloqüente." In: CIDADE, Hernani. Camões - o Épico. Lisboa: Editorial Presença, 2003
} 
Estando os cristãos surdos aos apelos dos outros povos cristãos citados nos versos acima, caberá aos portugueses a missão de combater o maometismo e assim, livrar todo o mundo dos "profanos/ Preceptos do Alcorão".

Isso posto, percebe-se que o vitupério ao mouro no Lugar de Nação não deve-se a outro motivo que não o de os habitantes das nações vituperadas seguirem o maometismo. E o vitupério às nações cristãs é devido ao fato de elas não defenderem a Lei cristã do "torpe Ismaelita".

\section{c) Lugar de Pátria}

porque as leis, os costumes, as opiniões das cidades são, eles também, diferentes $^{82}$

Pátria, no dicionário de Bluteau, ${ }^{83}$ possui uma acepção afetiva. É a terra, a vila, o Reino em que se nasceu.

Ama cada hu a sua pátria, como origem do seu ser, e centro do seu descanço. (...) O mais agradável domicilio, he o da casa paterna, e os que mais estimão os peregrinos mais que os sedentos na opinião de Plutarco, são como aquelles que preferem as estrellas fixas às errantes. (...) A pátria porem do sábio he toda a terra, onde pode viver honrada, e comodamente. Omne solum forti, pátria est. (...) Perguntado Socrates de que terra era, respondeo que era Cosmopolita, isto he, Habitador do mundo todo. ${ }^{84}$

A partir da definição de Quintiliano e da de Bluteau, nos aproximamos de um sentido para o termo Pátria. Se a Pátria é definida pelas leis, pelos costumes e sabendose que a lei Cristã é superior às leis dos homens, é a religião que define a Pátria, sendo a Pátria dos cristãos todo o mundo. Dessa maneira, devem os portugueses do século XVI, pelo bem da Pátria, estender a Fé cristã e velar por ela.

\footnotetext{
82 “patria, quia similiter etiam civitatium leges, instituta, opiniones habent differentiam” pag. 162.

${ }^{83}$ BLUTEAU, Raphael. Vocabulario Portuguez e Latino, aulico, anatomico, architectonico... Coimbra: No Collegio das Artes da Companhia de Jesu, 1712.

84 idem
} 
Segundo Aristóteles, as maiores virtudes são as que são mais úteis aos outros ${ }^{85}$. No século XVI ibérico não há maior virtude que expandir e preservar a Lei Católica, pois esta assegura o Bem Comum e sustenta o Corpo Místico representado pelos governos cristãos. Se Bem Comum e manutenção do Corpo Místico são assegurados pela Ortodoxia, virtuoso é lutar pela permanência desta. Sendo, portanto, a luta pela defesa da Fé cristã a máxima virtude.

Não devemos nos esquecer que Os Lusíadas foram escritos para um público cortês católico, dedicados a um rei católico e julgados por padres ${ }^{86}$. O vitupério aos mouros era algo esperado e previsto pelo leitor, habituado que estava a vê-lo desse modo em outros textos (crônicas historiográficas, autos, poemas etc) e ciente dos acontecimentos que atingiam a todos naquele momento, como a Reforma, a ContraReforma e o estabelecimento da Inquisição.

Arrogando-se o privilégio de ser uma pátria puramente cristã, Portugal não só não admitia que houvesse a mácula em seu solo de "sangue infiel" ${ }^{, 87}$ como se empenhava em expandir a Fé cristã.

Tal sentimento se traduz perfeitamente no seguinte verso: "não faltarão Christãos atrevimentos,/ Nesta pequena casa Lusitana" (Canto VII, 14).

Sendo, portanto, a Fé Católica o que garante a harmonia do Reino, acreditamos ser ela o principal elemento a se observar para o elogio ou o vitupério de uma pessoa, no poema. É por ter uma Fé outra, que os mouros são vituperados. Assim, quando Quintiliano preceitua que as Leis devem ser observadas, imagino que possamos considerar aqui as Leis religiosas, já que em Os Lusíadas, religião e doutrina política se confundem, se mesclam e se complementam.

\footnotetext{
${ }^{85}$ ARISTÓTELES. Retórica.

${ }^{86}$ O Censor do Santo Ofício, que liberou a publicação da obra, em 1572.

${ }^{87}$ SICROFF, Albert. Los Estatutos de Limpieza de Sangre. Madrid: Taurus Ediciones S.A., 1985. Ter sangue judeu ou mouro era vergonhoso e vedava o acesso a cargos honoríficos ou administrativos.
} 


\section{c.1) Lei $^{88}$}

O termo Lei se repete ao longo do poema e pode-se afirmar que em quase todas as ocorrências, significa Lei religiosa. Será elogiada se for a católica e vituperada se for a maometana ou a gentílica.

\section{Canto I, 53}

"Somos, hum dos das Ilhas lhe tornou,/ Estrangeiros na terra, Lei e nação,/ Que os próprios, sam aquelles que criou/ A Natura sem Lei, e sem Razão:/ Nós temos a Lei certa que insinou,/ O claro descendente de Abrahão:/ Que agora tem do Mundo o senhorio,/ A mãe Hebreia teve, e o pai Gentio"

Assim se descreve um dos habitantes da Ilha de Moçambique a Vasco da Gama quando este lá esteve. O nativo refere-se a Maomé, descendente de Abraão. Se a Natura os criou sem Lei e sem Razão, deu-lhes Maomé uma Lei para seguir. E esta "tem do mundo o senhorio" por ter se expandido pelo mundo. Logo, não é uma Lei inofensiva, mas uma Lei que se impõe e que ameaça os domínios cristãos. É o nativo que diz ser a Lei maometana "certa". Sendo ele estrangeiro na terra, lei e nação; criado pela Natura sem lei e sem razão, não é ele uma pessoa hábil para avaliar se a Lei maometana é certa ou não. Seu barbarismo o torna um inepto.

\section{Canto II, 102}

"E com grandes palavras lhe oferece/ Tudo o que de seus reinos lhe comprisse;/ E que, se mantimento lhe falece,/ Como se próprio fosse, lho pedisse./ Diz lhe mais, que por fama bem conheçe/ A gente Lusitana, sem que a visse,/ Que já ouviu dizer, que noutra terra/ Com gente de sua ley tivesse guerra"

Os versos citados são proferidos pelo rei de Melinde, que pede ao Gama que lhe narre as guerras havidas entre os cristãos e a "gente de sua ley", ou seja, maometanos. $\mathrm{O}$ rei de Melinde é um dos personagens mais interessantes do poema. É, junto à Monçaide, os únicos mouros a serem elogiados no poema.

\footnotetext{
${ }^{88}$ Segundo Bluteau, em seu já citado dicionário, o termo lei possui inúmeros usos, sendo os mais comuns os referentes à "vontade absoluta de qualquer soberano autenticamente manifesta que manda ou prohibe alguma cousa aos vassallos" e à religião "Ley, se diz em termos de Religião. a Ley de Deos, a ley de Moyses, a ley da Graça, ou a ley Evangélica, na qual nosso Senhor Jesu Christo fundou a Christandade. A lei da natureza he o fundamento de todas as leys".
} 


\section{Canto III, 113}

"Eis as lanças e espadas retiniam/ Por cima dos arneses (bravo estrago!);/ Chamão (segundo as leis que ali seguião)/ Hus Mafamede, e os outros Sanctiago./ Os feridos com grita o céu feriam,/ Fazendo de seu sangue bruto lago,/ Onde outros, meios mortos, se afogavam,/ Quando do ferro as vidas escapavam"

Referência a "Santiago Mata-Moros", santo católico que lutou contra os mouros na Reconquista ${ }^{89}$ e nessa luta perdeu a vida. Segundo Américo Castro, a devoção a Santiago em Espanha era muito forte. O hispanista afirma que "La creencia difusa e inconexa em Santiago, (...) adquirió volumen y estrutura como una fé opuesta y, en cierto modo, similar a la musulmana." O nome do santo se transformou em grito católico de guerra, oposto ao grito dos maometanos. "En 1140 se dice en el Poema del Cid, máximo heroe de la cristandad hispana: 'Los moros llaman Mafomat, e los cristianos Santi Yague' "90. João de Barros também cita a devoção à Santiago quando narra uma viagem feita por Nuno Tristã à região do Cabo Bojador: "E foy tal sua ventura que foram dar com os mouros onde jaziam recolhidos (...), chegando aos quaes começaram com grãde grita dizer, Portugal Portugal Santiago."91

\section{Canto IV, 48}

"Não sofre o peito forte usado aa guerra/ Não ter imigo ja a quem faça dano,/ E assi não tendo a quem vencer na terra/ Vay cometer as ondas do Occeano:/ Este he o primeiro Rey que se desterra/ Da patria, por fazer que o Africano/ Conheça pollas armas, quanto excede/ A ley de Cristo aa ley de Mafamede"

Os mouros são expulsos de Portugal em 1249. No século seguinte, o rei D. Duarte ataca Ceuta e a toma dos mouros. É a ele que o poeta se refere quando diz que é o primeiro rei que da pátria se desterra. O poeta também sintetiza não apenas a causa desse momento específico, mas também das navegações portuguesas: combater os maometanos e dilatar a Fé Católica, mesmo que com esforço armado. É o que

\footnotetext{
89 "Àquela ilha aportamos que tomou/ O nome do guerreiro Santiago/ Santo que os espanhóis tanto ajudou a fazer nos mouros bravo estrago" (Canto V, 9).

${ }^{90}$ CASTRO, Américo. España en su História: Ensayos sobre Historia y Literatura. Madrid: Editorial Trotta, 2004. Pag. 135.

${ }^{91}$ BARROS, João de. Ásia. Primeira Década. Pag. 27.
} 
percebemos a partir dos versos "por fazer que o Africano/ Conheça pollas armas, quanto excede/ A ley de Christo aa ley de Mafamede".

$$
\text { Canto IV, } 100
$$

"Não tens junto com tigo o Ismaelita/ Com quem sempre teras guerras sobejas?/ Não segue elle do Arabio a ley maldita,/ Se tu polla de Christo só pellejas?/ Não tem cidade mil, terra infinita,/ Se terras e riquezas mais desejas?/ Não he ele por armas esforçado,/ Se queres por victorias ser louvado?”

A citação acima pertence ao episódio do Velho do Restelo, que é um dos mais significativos do poema. Aparentemente trata-se de uma crítica às navegações. Chama a estas "Fontes de desamparos e adultérios/ Sagaz consumidora conhecida/ De fazendas, de reinos e de impérios". E diz que, se, como os portugueses afirmam sempre, sua motivação maior é a luta contra o Ismaelita, por este seguir "do Arábio a ley maldita", por que buscá-lo lá nas terras do Oriente se este está às portas do reino, na África? Na luta contra o Mouro africano os portugueses alcançariam tudo o que afirmavam desejar: terras, riquezas, batalhas e, principalmente, dilatação da Fé. O porquê de eles insistirem em se arriscar nos empreendimentos marítimos, em viagens tão longas e perigosas não é entendido pelo Velho. Crê que é por desejos de glória, de poder, de vaidade. Motivos pouco nobres, viciosos já que coloca em risco todo o Reino. No entanto suas palavras são vãs, a ninguém atingem. Os portugueses o ouvem, mas não o obedecem e, são bem sucedidos. Conseguem tudo o que desejavam e as navegações realizam-se como um empreendimento português que muda toda a concepção que se tinha do mundo.

Apesar de tantas perdas, tantas mães sem filhos, tantas esposas sem maridos, tantos filhos sem pais, apesar de os custos serem incomensuráveis e o Reino ficar sem lavradores e soldados, os portugueses conquistam mais pessoas para a Lei de Cristo, além de terras, riquezas, batalhas, fama, glória e apresentam ao mundo lugares até então desconhecidos pela maioria dos povos: "E se mais mundo houvera lá chegara"

O que, aparentemente, era uma crítica, torna-se um momento de reflexão no qual a vitória do empreendimento marítimo é exaltada, pois conquistada à custa de muito esforço, determinação e sofrimento. 


\section{Canto VII, 3}

"Vós, Portugueses, poucos quanto fortes,/ Que o fraco poder vosso não pesais;/ Vós que aa custa de vossas varias mortes,/ A lei da vida eterna dilatais:/ Assi do Ceo deitadas são as sortes/ Que vós, por muito poucos que sejais,/ Muito façais na santa Cristandade,/ Que tanto, ó Cristo, exaltas a humildade"

"Lei da vida eterna", lei de Cristo. Esse verso, junto a outros que lhe seguem tecem o elogio aos portugueses que arriscam as próprias vidas pela dilatação da Fé católica, mesmo sendo em pequeno número, o que os dignifica ainda mais.

\section{Canto VII, 17}

"Jugo de Reis diversos o constrange/ A várias leis: algus o vicioso/ Mahoma, algus os Idolos adorão,/ Algus os animais, que entre elles morão"

Os versos acima referem-se à Calecute, cidade onde se encontram diversos credos, entre estes o maometismo e o hinduísmo. Há aqui uma equivalência entre as leis do "vicioso Mahoma" e a dos que adoram ídolos ou animais. São viciosas e falsas.

\section{Canto VIII, 47}

"A isto mais se ajunta que hum devoto/ Sacerdote da ley de Maphamede,/ Dos odios concebidos nam remoto,/ Contra a divina Fe, que tudo excede/ Em forma do Propheta falso e noto,/ Que do filho da escrava Agar procede,/ Baco odioso em sonhos lhe aparece,/ Que de seus ódios inda se nam deçe"

No maometismo não há sacerdotes como no cristianismo. Por analogia, Camões crê ser o personagem um sacerdote ${ }^{92}$. O conhecimento que os cristãos tinham a respeito dos credos não-cristãos era muito limitado. Segundo Boxer, os padres e missionários evitavam ter um contato mais direto e aprofundando com as "seitas", pois temiam ser contaminados ou que o demônio os enganasse de alguma forma ${ }^{93}$. Além disso, naquela

\footnotetext{
92 Provavelmente um Imam.

93 "Convencidos como estavam da superioridade moral - e normalmente material - do cristianismo ocidental, só o missionário de excepção se dava ao trabalho de perder tempo a estudar profundamente os livros sagrados (onde os havia) e as crenças básicas daqueles que tentavam converter, como o fizerem, por exemplo, Sahagún no México, Ricci na China e Nobili na India. Muitos dos portadores da semente evangélica tinham tendência para rejeitar essas crenças como obras do demônio e todas as
} 
época, tudo era explicado a partir da exegese cristã. Bastava saber que a Lei de Maomé era um castigo divino, conforme afirmavam as autoridades eclesiásticas, ou uma provação, conforme previsões retiradas da Bíblia ${ }^{94}$.

\section{Canto IX, 94}

"Ou day na paz as leis iguais, constantes,/ Que aos grandes não dem o dos pequenos,/ Ou cos vesti nas armas rutilantes,/ Contra a ley dos imigos Sarracenos:/ Fareis os Reinos grandes e possantes,/ E todos tereis mais e nenhum menos:/ Possuireis riquezas merecidas/ Com as honras que ilustram tanto as vidas"

Tais versos fazem parte dos excursos do poeta sobre o dinheiro e a busca vã por ouro e glórias. O poeta pede que sejam dadas aos povos "leys iguais, constantes", pois assim evita-se a desarmonia no Reino. Combatendo a "ley dos imigos Sarracenos", que por ser do inimigo é inválida, aproxima-se a realização desse desejo.

\section{Canto X, 14}

“Chamará o Samorim mais gente nova;/ Virão Reis de Bispur e de Tanor,/ Das serras de Narsinga, que alta prova/ Estarão prometendo a seu senhor;/ Fará que todo o Naire, enfim, se mova/ Que entre Calecu jaz e Cananor,/ Dambas as leis immigas, pera a guerra,/ Mouros por mar, Gentios polla terra"

Palavras proferidas pela Deusa Tétis, profetizando os perigos e as resistências que os portugueses enfrentarão nas terras do Oriente. Eles se verão cercados pelos seus inimigos, mouros e gentios; mas por fim, os portugueses vencerão e seus inimigos serão submetidos.

\section{Canto X, 108}

“As províncias, que entre hum e o outro rio/ Ves com várias nações, sam infinitas:/ Hum reino Mahometa, outro Gentio,/ A quem tem o Demonio leis escriptas/

culturas não cristãs como basicamente inferiores ou estranhamente exóticas", pag. 56. BOXER, Charles. A Igreja e a Expansão Ibérica (1440-1770). Lisboa: Edições 70, s.d. Ver também TOLAN, John. Les Sarrasins. Pag. 53.

94 “(...) la Bible et les écrits des Pères de l’Église, qui constituaient, en effet, une riche source d'explication: les prophètes hébreux, l'Évangile et le livre de l'Apocalypse évoquaient les tribulations des opresseurs infidèles. Ces passages furent donc remaniés et reinterpretés afin de donner un sens aux victoires musulmanes", pag. 15. TOLAN, John. Les Sarrasins. 
Olha que de Narsinga o senhorio/ Tem as relíquias santas e benditas/ Do corpo de Tomé, barão sagrado,/ Que a Jesu Crsito teve a mão no lado.”

As leis do reino Mahometa e do Gentio foram pelo demônio escritas. Para um leitor católico não pode haver leis mais erradas e abomináveis. Para a doutrina cristã é o demônio a origem de todos os vícios e toda prática não-cristã é demoníaca: “(...) pela mediação de "Satanás" a prática religiosa não-católica é "delírio", "loucura", classificação de irracionalidade que se estende ao judaísmo, islamismo, bramanismo, luteranismo, calvinismo etc., enquanto o catolicismo se eleva como racionalidade e verdade." 95

\section{Canto VII, 33}

"Porem como a esta terra entam viessem/ De lá do seyo Arábico outras gentes/ Que o culto Mahometico trouxessem,/ No qual me instituirão meus parentes,/ Succedeu que pregando convertessem/ O Perimal, de sábios e elloquientes;/ Fazem lhe a ley tomar com fervor tanto,/ que prosupos de nella morrer sancto"

Os maometanos converteram o Perimal pela força do argumento, da retórica; e não pela justeza e verdade de sua fé, tampouco por inspiração divina, como será Monçaide posteriormente convertido ao catolicismo. Quem tem a palavra nesses versos é Monçaide. Ele narra a história de Calecute e de seus governantes à frota de Gama. Afirma que Calecute é a mais rica e poderosa das terras repartidas pelo Perimal quando este se converteu ao maometismo e decidiu "morrer sancto". Sendo ele a falar, é verossímil que os maometanos que converteram o Perimal recebam os elogios de serem "sábios e elloquentes".

A lei religiosa, como vimos, é referida a todo o momento e, não sendo a cristã, é vituperada. Os vitupérios mais freqüentes que atingem as crenças não-cristãs são chamá-las de seitas ou superstição. Não são consideradas como outra religião, pois não existe, no século XVI ibérico, outra religião que não a Católica, já que Deus enviou aos

\footnotetext{
${ }^{95}$ HANSEN, João Adolfo. A Sátira e o Engenho. Campinas, Editora da Unicamp, 2002. pag 213
} 
homens uma única Lei ${ }^{96}$. O que existem são desvios, "todos os outros credos eram fundamentalmente falsos ou lamentavelmente deformados"97.

\section{c.2) Seitas}

\section{Canto I, 57}

“A noyte se passou na lassa frota,/ Com estranha alegria, e não cuydada,/ Por acharem da terra tão remota,/ Nova de tanto tempo desejada:/ Qualquer então consigo cuyda, e nota/ Na gente, e na maneira desusada./ E como os que na errada Seita crerão,/ Tanto por todo o mundo se estenderão"

\section{Canto VIII, 51}

"Isto dito, elle e o sono se despede,/ Tremendo fica o atonito Agareno,/ Salta da cama, lume aos servos pede/ Lavrando nelle o férvido veneno:/ Tanto que a nova luz que ao Sol precede/ Mostrara rosto Angelico e sereno,/ Convoca os principais da torpe ceita,/ Aos quais do que sonhou dá conta estreita"

Em Moçambique, os nativos crêem na "Seita errada", o maometismo. "Errada" e "torpe" são os epítetos que desqualificam a "ceita" fundada por Maomé. É a ausência da virtude que é destacada pelo poeta ao se valer de injúrias como essas. Ao apontar a falha, a falta, o erro e o pecado ${ }^{98}$, a virtude de ser cristão se destaca e se torna mais desejada, por ser o único caminho para a salvação.

\section{Canto VII, 75}

"Mas comer o Gentio nam pretende,/ Que a ceita que seguia lho defende"

A crença dos Gentios (ou Idólatras) é também designada como "ceita".

\footnotetext{
${ }^{96}$ Bluteau, como padre que era, utilizou para definir as palavras em seu dicionário, não apenas conhecimentos etimológicos, mas também teológicos. Assim ele inicia sua definição do termo Lei: "ou como outros escrevem Ley. Deriva-se do Latim Legi. (...) A primeira de todas he a ley natural, que he a recta razão do homem, inspirada, e ajudada com a razão divina. (...) As leys fundamentais devem ser eternas. Deos (...) deo ao mundo huma só Religião, mas quis q fosse diversamente observada dos Patriarcas na ley da Natureza, dos Judeos na ley Escrita, e dos Christãos na ley Evangélica. Também nesta ultima ley ha cousas immutaveis, a saber, os sagrados mysterios, que são o objecto da nossa Fé; Sacramentos, que são a matéria do nosso culto, e os Mandamentos do Decalogo, que respeitão os costumes; todos estes pontos são de direyto divino; nenhu poder inferior os pode mudar"

${ }^{97}$ BOXER, Charles. A Igreja e a Expansão Ibérica (1440-1770). Pag. 55.

${ }^{98}$ HANSEN, Joâo Adolfo. A Sátira e o Engenho.
} 


\section{c.3) Superstição}

Canto VII, 49

“Aqui feita do barbaro gentio/ A supersticiosa adoração,/ Direitos vão sem outro algum desvio,/ Pera onde estava o Rei do povo vão/ Engrossando se vay da gente o fio/ Cos que vem ver o estranho Capitão,/ Estão pelos telhados e janellas/ Velhos e moços, donas e donzellas"

\section{Canto IX, 2}

"La no seio Eritreo, onde fundada/ Arsinoe foi do Egipcio Ptholomeo,/ Do nome da irmã sua asi chamada,/ Que despois em Suez se converteo,/ Não longe, o porto jaz da nomeada/ Cidade Meca, que se engrandeceo/ Com a superstiçam falsa, e profana/ Da religiosa ágoa Maumetana"

Tanto a crença dos gentios quanto a dos mouros são consideradas superstições. Na definição de Bluteau, superstição: "he um culto, não devido ao verdadeyro Deos, ou a algum Idolo, ou falso, e fabuloso Nume. ${ }^{99 "}$ Tanto os gentios, com sua adoração supersticiosa, quanto os maometanos com sua superstição falsa e profana incorrem no erro de não prestarem culto ao "verdadeyro Deos".

\section{d) Lugar de Educação e Instrução}

Pois é importante saber por quem e de que maneira o acusado foi formado ${ }^{100}$

Os Mouros não aparecem como pessoas instruídas ou cultivadas. São eles designados no poema como bárbaros por várias vezes. Os gregos e os romanos chamavam a todos os estrangeiros, bárbaros. N'Os Lusíadas tal acepção é também encontrada, no entanto o termo "bárbaros" significa mais comumente no poema incivilizados, rústicos, brutos e cruéis.

Bárbaros como estrangeiros: Canto II, 110

\footnotetext{
${ }^{99}$ BLUTEAU, Raphael. Vocabulario Portuguez e Latino, aulico, anatomico, architectonico... Coimbra: No Collegio das Artes da Companhia de Jesu, 1712.

100 "educatio et disciplina, quoniam refert a quibus et quo quisque modo sit institus" pag, 164
} 
Bárbaros, incivilizados, rústicos, brutos e cruéis: Canto I, 62; Canto II, 29; Canto II, 41; Canto III, 48; Canto III, 75; Canto III, 76; Canto III, 85; Canto III, 86; Canto III, 100; Canto III, 103; Canto IV, 55; Canto V, 34; Canto V, 69; Canto V, 84; Canto VII, 13; Canto VIII, 84; Canto VII, 49.

João de Barros também destaca a incivilidade dos Mouros:

\begin{abstract}
"Nesta detença q Antam Gonçalvez fez de palavras, os mouros pero que bárbaros eram per natureza o temor os fez prudetes pera entendere que o a pinhoar dos nossos e deteça que fizerã sem se mover, fora cõsulta a cerca de os cometerem ou nam: e como gente q tinha mais conta cõ a vida q com a hora, virarãlhe as costas ${ }^{101,}$
\end{abstract}

Nesse trecho, João de Barros narra um ataque do bando de Antã Gonçalvez a uma tribo de mouros em Angra dos Cavallos ${ }^{102}$. O historiador português chama-os de bárbaros e afirma que, ao não socorrerem o companheiro que estava sendo levado prisioneiro, se preocupam mais com a vida que com a honra.

Recebem os mouros tais epítetos a fim de serem vituperados por sua incivilidade. Portugal não apenas lhes daria a "Verdadeira Fé", mas também a civilidade.

Há apenas dois mouros que recebem epítetos elogiosos do poeta: o rei de Melinde e Monçaide. Àquele chama de "pagão benigno" (VI,3) e a este de "Mauritano sábio"(VIII,1). Os dois são elogiados devido aos serviços que prestaram aos portugueses ${ }^{103}$. Monçaide é, inclusive, convertido ao cristianismo “(...) que a clemência/ Divina tirou da escura treva”(Canto IX, 15). E assim a ele é destinado o paraíso.

No poema há duas maneiras interligadas de se merecer o Paraíso: sendo cristão (ou convertendo-se como Monçaide) e morrendo-se na luta contra o Infiel. Vimos no primeiro capítulo exemplo dessa tópica. A luta contra o Infiel é uma luta de devoção "É guerra de devação/ por honra de vossa terra/ cometida com rezão/ formada com descrição/ contra aquela gente perra" ${ }^{104}$ e, por isso, quem nela perece embarca na "Barca do Paraíso", como vimos em Gil Vicente: "Ó Cavaleiros de Deos/ a vós estou

\footnotetext{
${ }^{101}$ BARROS, João de. Ásia, pag. 27.

102 Próxima ao Cabo Bojador.

103 DOMINGUES, José Garcia. A Concepção do Mundo Árabe-Islâmico n'Os Lusíadas.

${ }^{104}$ VICNETE, GIL. Exortação à Guerra. Pag. 678.
} 
esperando/ que morrestes pelejando/ por Cristo senhor dos céus./ Sois livres de todo mal/ santos por certo sem falha/ que quem morre em tal batalha/ merece paz eternal."105

Rui de Pina também afirma que os cristãos, na Batalha de Salado, estavam dispostos a "morrer por quem por elles primeyro morrera".

N’Os Lusíadas é Fuas Roupinho um exemplo de cristão morto em luta contra os mouros:

Canto VIII, 17

"E dom Fuas Roupinho que na terra,/ E no mar resplandece juntamente,/ Co fogo que acendeo junto da serra/ De Ábila, nas gales da Maura gente./ Olha como então justa e sancta guerra/ De acabar pelejando está contente:/ Das mãos dos Mouros entra a felice alma/ Triunfando nos ceos com justa Palma"

Duarte Galvão, em sua crônica sobre o Rei Afonso Henriques, assim narra a morte de Fuas Roupinho:

Os mouros, sentidos dos dampnos feitos pu dom Fuas, rreçeamdosse de mais ao diante, mamdaram sobre ello rrequado per toda a mourisma da praya, e também das partes dEspanha: e ajuntaram çimcoemta e quatro galles: e dom Fuas, nam sabenmdo desto, parte enmtrou pello estreito com uemto forçoso que o fez correr de lomgue pello estreito a demtro, e depois achousse lla com as galles dos mouros. E polla corremte gramde lamçar nas nossas galles sobre a frota dos jmijguos, nam poderam os nossos all fazer senam pelleiar com elles: e assim aferraram e pelleiaram mujto, mas polla gramde desiguallamça dos mouros serem mujtio mais, foram os nossos vemçidos e desbaratados, e mortos mujtos, e amtre elles dom Fuas Roupinho ${ }^{106}$

Embora os cronistas também tivessem o compromisso de narrarem ações exemplares, virtuosas, que atendessem às determinações da Igreja; o épico, por ser poesia, possibilitava uma Inventio mais livre, devido ao fato de o poema não ter

\footnotetext{
${ }^{105}$ VICENTE, Gil. Auto da Barca do Inferno. Pag. 242.

${ }^{106}$ GALVÃO, Duarte. Crônica de El-Rei D. Afonso Henriques. Pag. 194.
} 
compromisso com a verdade, mas com a verossimilhança. Camões, ao narrar a morte de dom Fuas, a "melhora" a fim de que afete seus leitores e lhes sirva de exemplo ${ }^{107}$.

\section{e) Lugar dos Caracteres}

pois a avareza, a cólera, a piedade, a crueldade, a severidade e outros traços semelhantes determinam frequentemente a crença ou a descrença (se examina ao mesmo tempo se o tipo de vida é suntuoso, frugal ou sórdido) $)^{108}$

\section{e Lugar de Palavras e Ações}

Faz-se necessário igualmente considerar o que cada pessoa deseja parecer, rica ou eloqüente, justa ou influente. Examina-se as ações e as palavras anteriores, porque o passado, ordinariamente, serve para julgar o presente ${ }^{109}$.

Os lugares dos Caracteres e de Palavras e Ações serão abordados conjuntamente, pois embora haja versos em que os caracteres se mostrem independente das ações ${ }^{110}$, é nestas que eles se realizam.

Duas são as preceptivas que nos fornecem um inventário de vícios e virtudes que podem formar o ethos dos personagens: Ética a Nicômaco, de Aristóteles e Os Caracteres, de Teofrastro. Apesar de este ser, sobretudo uma "obra concebida como um repertório de retratos cômicos, exagerados até a caricatura, frutos da observação do comportamento psicológico de um contexto social determinado" ${ }^{111}$, as definições dadas pelo autor aos vários tipos de caracteres nos serão úteis, pois o que ele seleciona são os tipos especialmente dignos de repreensão, logo, de vitupério. O Ética a Nicômaco nos

\footnotetext{
107 “(...) tudo o que conta por verdade a historia, deve a mesma Epopeia melhorar por moralidade” Manuel Pires de Almeida. Cltado por MUHANA, Adma. A epopéia em prosa seiscentista. pag. 123.

108 "animi natura, etenim avaritia, iracundia, misericirdia, crudelitas, severitas aliaque his similia afferunt fidem frequenter aut detrahunt, sicut victus luxuriosus na frugi na sordidus quaeritur" pag. 164.

109 "Intuendum etiam quid affectet quisque, locuples videri na disertus, Justus na potens. Spectantur ante acta dictaque; ex praeteritis enim aestimari solent praesentia” pag. 164.

${ }^{110}$ Nos excursos do poeta, principalmente. Por exemplo: Canto VII, 2 “A vos, ó geraçam de Luso digo,/ Que tam pequena parte sois do mundo:/ Não digo no mundo, mas no amigo/ Curral de quem governa o çeo rotundo/ Vos, a quem não somente algum perigo/ Estorva conquistar o povo inmundo:/ Mas nem cobiça, ou pouca obediência/ Da Madre, que nos çeos está em essência."

${ }^{111}$ TEOFRASTO. Os Caracteres. Tradução de Daisi Malhadas e Haiganuch Sarian. Sâo Paulo, E.P.U., 1978. Introdução, pag. 21.
} 
será ainda mais necessário, pois os conceitos de virtude que a obra traz pouco se distancia do que, posteriormente, passou a ser recomendado pela Igreja Católica, pelas vias de São Tomás de Aquino. Sendo a ausência de virtude o que caracteriza o vício, acreditamos que, no poema, o comportamento vicioso dos mouros seja resultado de sua não-adesão ao Catolicismo, já que o ‘ser-cristão’ no século XVI era a virtude essencial.

Seja na guerra ou na paz, os mouros são descritos, predominantemente em $O s$ Lusíadas, como covardes e falsos. É o que constataremos a seguir.

\section{e.1) Em Moçambique}

Percebendo que os portugueses eram cristãos "sequazes da verdade/ Que o filho de David nos ensinou" (Canto I, 71), e não maometanos como gostariam, os moçambicanos se indispõem:

\section{Canto I, 69}

"Poren disto que o Mouro aqui notou/ E de tudo o que vio, com olho atento,/ Hum ódio certo na alma lhe ficou/ Hua vontade má de pensamento/ Nas mostras, e no gesto o não mostrou,/ Mas com risonho, e ledo fingimento,/ Tratalos brandamente determina,/ Até que mostrar possa o que imagina"

O fingimento e a dissimulação do Mouro são destaques nessa estância. Movido pelo ódio, pela ira, o Mouro planeja uma armadilha que destrua os cristãos. Sabendo ser desejo dos cristãos encontrar um piloto que os conduza às Índias, o Mouro ${ }^{112} \mathrm{o}$ oferece com o intuito que ele os conduzisse à perdição. Mas, antes que a frota de Gama deixasse Moçambique, são os portugueses atacados pelos nativos "belicosos Mouros" (Canto I, 87). Mas, vendo estes, a superioridade das forças portuguesas,

\section{Canto I, 89}

"Eis nos bateis o fogo se levanta,/ Na furiosa e dura artilheria,/ a plumbea pela mata, o brado espanta:/ Ferido o ar retumba, e assovia:/ O coraçam dos Mouros se quebranta,/ $O$ temor grande o sangue lhe resfria./ Já foge o escondido de medroso/ E morre o descoberto aventuroso."

\footnotetext{
${ }^{112}$ Acatando o conselho de Baco, que se disfarçou de Mouro "Velho, sábio e co Xeque mui valido"(Canto I, 77)
} 


\section{Canto I, 91}

"Fugindo, a seta o Mouro vay tirando,/ Sem força, de covarde, e de apressado,/ A pedra, o pao, e o canto arremessando,/ Dalhe armas o furor desatinado:/ Ia a Ilha, e todo o mais, desemparando,/ Aa terra firme foge amedrontado./ Passa, e corta do mar o estreito braço,/ Que a Ilha em torno cerca, em pouco espaço"

Em qualquer batalha, não há vício pior que a covardia.

"As maiores virtudes são necessariamente as que são mais úteis aos
outros, posto que a virtude é a faculdade de fazer o bem. Por esta
razão se honram sobretudo os justos e os corajosos, pois a virtude
destes é útil aos demais na guerra, e a daqueles é útil também na
paz"113

E são os Mouros descritos como covardes. São também descritos como dissimulados. Para Teofrasto, dissimulado é o homem que, "ao se aproximar de seus inimigos busca esconder que os odeia; louva quando presentes os que atacou às ocultas" "114. Sendo assim são os Mouros dissimulados, pois mesmo tendo sido derrotados, fingem se arrepender da agressão cometida contra os portugueses e lhes oferecem o prometido e desejado piloto:

\section{Canto I, 96}

"O Capitão, que não cahia em nada/ Do enganoso ardil que o Mouro urdia"

aceita o piloto de bom grado. Mas a frota, que estava sendo por este conduzida à Ilha de Quiloa, “(...) a Ilha é possuída da malina/ Gente que segue o torpe Mahamede” (I, 99), é desviada por ventos e lá não aporta.

\section{Canto I, 101}

"Mas o malvado Mouro nam podendo,/ Tal determinação levar avante,/ Outra maldade inica cometendo,/ Ainda em seu propósito constante/ Lhe diz, que, pois as agoas discorrendo,/ OS levarão por força por diante,/ Que outra Ilha tem perto, cuja gente,/ Erão Christãos com Mouros juntamente"

\footnotetext{
${ }^{113}$ ARISTÓTELES, Retórica. pag 74.

${ }^{114}$ TEOFRASTO. Os Caracteres. pag, 34.
} 
Aristóteles diz na Retórica:

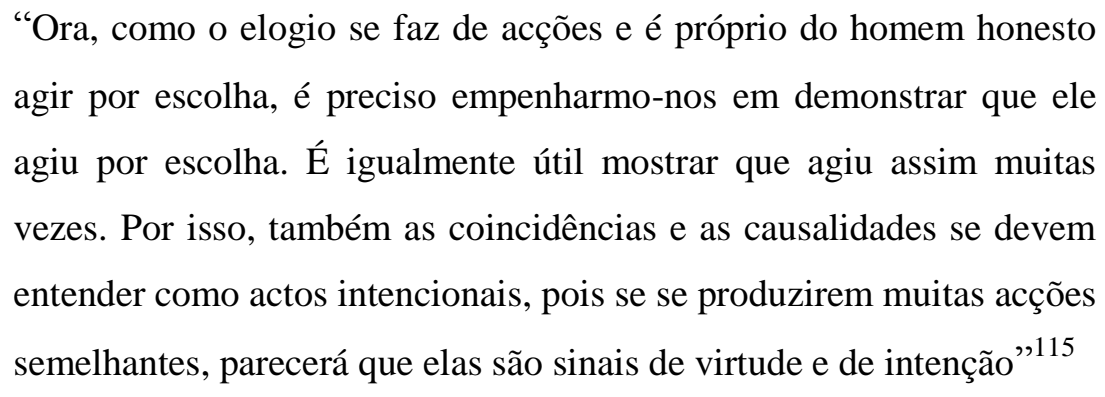

Sendo a preceptiva para o vitupério a mesma que para o elogio, só que pelos seus contrários, deduz-se que, a partir do exposto, tendo o piloto Mouro agido por escolha, insistindo na condução da frota em direção a maiores perigos, é ele vicioso, pois é malvado e dissimulado.

\section{e.2) Em Mombaça}

São os Mouros descritos como infiéis, covardes, enganosos e dissimulados:

\section{Canto II, 6}

"Perguntalhe despois, se estão na terra/ Christãos, como o Piloto lhe dezia,/ O mensageiro astuto que não erra,/ Lhe diz, que a mais da gete em Christo cria:/ Desta sorte do peito lhe desterra/ Toda a sospeita, e cauta fantasia:/ Por onde o Capitão seguramente,/ Se fia da infiel e falsa gente."

Vasco da Gama, fiado nas palavras do piloto mouro que o conduz a uma armadilha, aporta em Mombaça. Esta é habitada pela "infiel ${ }^{116}$ e falsa gente" e todos com quem trata Gama estão empenhados em enganá-lo como se percebe na estância abaixo:

\footnotetext{
${ }^{115}$ ARISTÓTELES. Retórica. pag. 77. E também: “A virtude, entretanto, concerne a paixões e ações, e o louvor e a censura são conferidos somente às ações voluntárias; aquelas que são involuntárias são objeto de perdão e, por vezes, até de compaixão". Ética à Nicômaco. pag. 87.

116 "Infiel. Aquelle que não tem fidelidade, que falta a fé devida, que não tem palavra. (...) Os infiéis, Aquelles que não professão a ley de Jesu Christo, e particularmente os sequazes de Mafoma, porque os mais se chamão Judeos, ou Idolatras" BLUTEAU, Raphael.
} 
Canto II, 16

"Co isto o nobre Gama recebia/ Alegremente os Mouros que subião,/ Que levemente hum animo se fia/ De mostras que tão certas parecião/ A nao da gente pérfida se enchia/ Deixando a bordo os barcos que trazião:/ Alegres vinhão todos, porque crem/ Que a presa desejada certa tem."

São "gente pérfida", por serem traiçoeiras e malvadas.

Canto II, 9

"E despois que ao Rei apresentarão,/ Co recado os presentes que trazião,/ A Cidade correrão, e notarão/ Muito menos daquillo que querião/ Que os Mouros cautelosos se guardarão/ De lhe mostrarem tudo o que pedião/ Que onde reina a malícia está o receio/ Que a faz imaginar no peito alheio."

É a cautela dos Mouros originada pela malícia. Eles agem com cuidado a fim de que a armadilha que armam para os cristãos não seja descoberta.

Canto II, 28

“Assi fogem os Mouros e o piloto/ Que ao perigo grande as naos guiara/ Crendo que seu engano estava noto/ Tambem foge saltando na agoa amara:/ Mas por nam darem no penedo immoto/ Onde percão a vida doce, e cara:/ A ancora solta logo a capitaina/ Qualquer das outras junto della amaina"

Ao serem descobertos e temendo o castigo que lhes poderiam dar os portugueses, os mouros fogem. É, mais uma vez, destacada a covardia dos mouros.

Vendo o quanto correra perigo nas mãos da "pérfida inimiga e falsa gente" e sabendo-se salvo pela "guarda soberana", Vasco da Gama agradece e louva a Deus e, ao mesmo tempo clama que Ele o conduza em segurança às Índias, pois é por Seu serviço que os portugueses navegam:

Canto II, 30

“O caso grande, estranho, e não cuydado,/ O milagre clarisimo, e evidente,/ O descoberto engano inopinado,/ O pérfida inimiga, e falsa gente,/ Quem poderá do mal 
aparelhado/ Livrarse sem perigo sabiamente,/ Se la de cima a guarda soberana,/ Não acudir aa fraca força humana?"

\section{Canto II, 32}

"E se Te move tanto a piedade,/ Desta mísera gente peregrina,/ Que só por tua altíssima bondade,/Da gente a salvas, pérfida e malina,/ Nalgum porto seguro de verdade:/ Conduzirnos já agora determina,/ Ou nos mostra a terra que buscamos,/ Pois só por Teu serviço navegamos."

Apenas a "guarda soberana" pode livrar os portugueses dos perigos e principalmente da gente "falsa, maligna e pérfida" dos mouros. A Divina Providência os acode, pois são os mouros um perigo da qual devem os lusitanos serem salvos. E graças a Ela, chegam os navegantes portugueses ao porto seguro de Melinde.

\section{e.3) Na Batalha de Ourique}

A Batalha de Ourique é narrada por Vasco da Gama ao rei de Melinde, após um pedido deste para que Gama relate as batalhas havidas entre mouros e cristãos.

\section{Canto III, 42}

"Mas já o Príncipe Affonso aparelhava/ O Lusitano exército ditoso,/ Contra o Mouro que as terras habitava,/ Dalém do claro Tejo deleitoso./ Já no campo de Ourique se assentava/ O arraial soberbo, e belicoso,/ Defronte do inimigo Sarraceno,/ Posto que em força, e gente tão pequeno"

Nesses versos é a desproporção das forças que se destaca. Estão os portugueses em menor número em relação ao "inimigo Sarraceno".

\section{Canto III, 43}

"Em nenhua outra cousa confiado,/ Senão no summo Deos, que o Ceo regia,/ Que tam pouco era o povo bautizado/ Que pera hum só cem Mouros averia/ Julga qualquer juyzo sossegado,/ Por mais temeridade que ousadia,/ Cometer um tamanho ajuntamento,/ Que pera hum cavalleiro ouvesse cento" 
Apesar da superioridade numérica do exército dos Mouros, confiam os cristãos no favorecimento divino. O elogio, segundo Quintiliano, deve ser retirado da alma, do corpo ou das circunstancias externas ${ }^{117}$. Numa luta desigual numericamente, os cristãos merecem elogios, pois são corajosos já que enfrentam um inimigo mais numeroso.

Canto III, 46

"Com tal milagre, os ânimos da gente/ Portuguesa, inflamados levantavão/ Por seu Rei natural, este excelente/ Principe, que do peito tanto amavão:/ E diante do exército potente/ Dos imigos, gritando o ceo tocavão:/ Dizendo em alta voz, real, real/ Por Affonso alto Rei de Portugal”

Nessa estância há a valorização do inimigo. Não há glória em vencer um oponente fraco. Glória há em vencê-lo sendo ele forte e numeroso, como o é "exército potente" dos Mouros, pois assim se destaca não apenas o valor "bélico" dos portugueses, sua coragem e força, mas também o favorecimento divino. Este é devido à justeza da causa portuguesa.

\section{Canto III, 47}

"Qoal cos gritos e vozes incitado,/ Pola montanha o rábido Moloso/ Contra o touro remete, que fiado/ Na força está do corno temeroso:/ Ora pega na orelha, ora no lado/ Latindo mais ligeiro que forçoso,/ Até que em fim rompendolhe a garganta,/ Do bravo a força horrenda se quebranta"

Eis nessa estância uma referência ao Lugar de Constituição Física ${ }^{118}$. Nesses versos são os portugueses comparados a um "rábido moloso" e sua ligeireza é elogiada, em contrapartida à aparente força dos mouros, comparados a um "touro". Tal passagem remete-nos à história bíblica de Davi e Golias ${ }^{119}$.

\footnotetext{
117 "Ipsius vero laus hominis ex animo et corpore et extra positis peti debet". QUINTILIANO. Intitution Oratoire. Vol. 1. Pag. 375.

118 " habitus corporis, ducitur enim frequenter in argumentum species libidinis, robur petulantiae, his contraria in diversum". O Lugar de Constituição Física não será tratado pormenorizadamente, por ser pouco utilizado.

${ }^{119}$ Também retomada em Canto III, 111; na narração da Batalha de Salado.
} 
Na estância seguinte, são os Mouros chamados de "perros". São os portugueses comparados a um "rábido moloso ${ }^{120}$ ", cão de caça, ligeiro e robusto, de raça; já os mouros são comparados a um "perro", cão vagabundo e ordinário.

Canto III, 50

"Desta arte o Mouro atônito e torvado/ Toma sem tento as armas muy depressa/ Não foge, mas espera confiado/ E o ginete belígero arremessa./ O Português o encontra denodado/ Pelos peitos as lanças lhe atravessa;/ Uns caem meio mortos, outros vão/ A ajuda convocando do Alcorão"

Os mouros não fogem, mas esperam confiantes. Não se pode considerá-los corajosos nessa passagem, pois a coragem pressupõe escolha e conhecimento dos riscos. Estão eles atônitos e torvados, ou seja, agem precipitadamente e irrefletidamente. Além disso, ignoram que são os cristãos ajudados por Deus e que a ajuda que convocam do Alcorão é vã. A aparente coragem dos mouros é, pois, temeridade irrefletida e gladiatória ${ }^{121}$ ("belicosos Mouros", Canto I, 87).

\section{e.4) Na Batalha de Salado}

Canto III, 100

"Nunca com Semirâmis, gente tanta/ Veio ôs campos Ydáspicos enchendo,/ Nem Atila, que Italia toda espanta,/ Chamandose de Deos açoute horrendo/ Gottica gente trouxe tanta, quanta/ Do Sarraceno bárbaro estupendo/ Co poder excessivo de Granada/ Foy nos campos Tartesios ajuntada"

É mais uma vez a desproporção numérica destacada. O exército sarraceno é superior ao cristão.

Canto III, 103

"Quantos povos a terra produzio/ De África toda gente fera e estranha,/ O grão Rei do Marrocos conduzio/ Pera vir possuir a nobre Espanha:/ Poder tamanho

\footnotetext{
${ }^{120}$ Moloso: "3. Se dice de cierta clase de perros procediente de Molosia". Do Diccionario de la lengua española. Disponível em: http://buscon.rae.es/drael/SrvltConsulta?TIPO_BUS=3\&LEMA=moloso.

${ }^{121}$ Retórica a Herênio. pag. 157.
} 
junto não se vio,/ Despois que o salso Mar a terra banha./ Trazem ferocidade, e furor tanto,/ Que a vivos medo, e a mortos faz espanto"

Os versos acima são ditos pela rainha Dona Maria. Ela mostra-se assustada e aflita pela ameaça que chega às terras de Castela, onde seu marido é rei. O poder dos Mouros é grande e o perigo, real. O rei do Marrocos, junto a outros africanos "gente fera e estranha" pretende conquistar terras castelhanas. Temendo por seu marido e pelo reino deste, D. Maria vai a Portugal pedir ajuda à seu pai, o rei D. Afonso IV. Este acata seu pedido e diz aos "principais da corte" que tentaram dissuadi-lo de ir socorrer o genro, conforme nos é narrado por Rui de Pina: “(...) dizendo com palavras animozas, e de grande confiança, que o verdadeiro e leal Portugues onde quer que estivesse por obras, e bom coraçam o seguiria indo contra os imigos da Fee, e por defensão da terra dos Christãos." 122

Canto III, 109

"Juntos os dous Affonsos finalmente,/ Nos campos de Tarifa, estão defronte/ Da grande multidão da cega gente,/ Pera quem sam pequenos campo e monte./ Não há peito tão alto e tam potente/ Que de desconfiança não se afronte,/ Em quanto não conheça, e claro veja, /que, co os braços dos seus, Christo peleja"

Os dois reis, confiados na ajuda divina, enfrentam a "multidão da cega gente". São os maometanos cegos por não verem que a verdadeira fé é a cristã: “(...) não vendo como cegos nem sabendo como ignorantes, aquelle certo atalho, do verdadeyro juízo de Deos, e nosso Senhor Iesus Christo" ${ }^{2123}$. Estão confiantes e enfrentam bravamente o inimigo porque Cristo peleja ao lado deles ${ }^{124}$.

Canto III, 110

"Estão de Agar os netos casi rindo,/ Do poder dos Christãos fraco e pequeno,/ As terras como suas repartindo,/ Ante mão, entre o exército Agareno:/

\footnotetext{
122 PINA, Rui de. Chronica de ElRey Dom Afonso o Quarto do Nome, e Settimo dos Reys de Portugal. Pag. 437.

${ }^{123}$ idem, pag. 434.

${ }^{124}$ Cristo peleja a favor dos portugueses: "Que em casos tão estranhos claramente/ Mais peleja o favor de Deos que a gente" (Canto III, 82); "Desta arte o Mouro pérfido despreza,/ O poder dos Christãos, e não entende,/ Que está ajudado da alta fortaleza/ A quem o Inferno horrífico se rende ( Canto III, 112)
} 
Que com título falso possuindo/ Está o famoso nome Sarraceno./ Assi também com falsa conta e nua,/ Aa nobre terra alhea chamão sua"

Os maometanos agem de maneira temerária, inconsequente e arrogante ao rirem do poder dos cristãos, menor e mais fraco. Crêem que sairão vitoriosos. Pecam os mouros, pois, por temeridade, arrogância e falta de compaixão.

\section{Canto III, 113}

"Eis as lanças e espadas retinião,/ Por cima dos arneses, bravo estrago,/ Chamão (segundo as leis que ali seguião)/ Uns Mafamede, e os outros Sanctiago,/ Os feridos com grita o Ceo ferião/ Fazendo de sangue bruto lago, Pnde outros meios mortos se afogavão,/ Quando do ferro as vidas escapavão"

Cada guerreiro clama pelo auxilio das respectivas Leis que seguiam. São os mouros derrotados pelos cristãos e pode-se afirmar, por analogia, que é o maometismo derrotado pelo catolicismo.

\section{Canto III, 115}

"Já se hia o Sol ardente recolhendo,/ Pera a casa de Thetis, e inclinado/ Pera o Ponente o véspero trazendo,/ Estava o claro dia memorado,/ Quando o poder do Mauro, grande e horedo,/ Foi pelos fortes Reis desbaratado,/ Com tanta mortindade, que a memória/ Nunca no mundo vio tam gram victória"

Rui de Pina corrobora o que os versos acima afirmam: houve quatrocentos e setenta mil mortos nessa violenta batalha. Vinte do lado cristão e quatrocentas e cinqüenta mil do lado maometano ${ }^{125}$. Percebemos, tanto na crônica de Rui de Pina quanto no poema, a utilização da amplificação para engrandecer a vitória lusitana. Semelhante amplificação se aproxima do inverossímil se desconsiderarmos que Deus lutou ao lado dos cristãos. Segundo Aristóteles, é melhor um verossímil impossível que um inverossímil possível. A narração da Batalha de Salado nas duas obras citadas

\footnotetext{
125 "E o numero certo das gentes dos Christãos que foram nesta batalla, assim de Portugal, como de Castella, eu nãm achey declarado, sõmente que erão menos a quarta parte da gente dos Mouros, e que so Christãos mortos por grande milagre nam passarão de vinte, e dos Mouros segundo despois se soube pelos seus alcaizes que sam como livros dalardo, e apurações e que todos os que passaram a Espanha eram escritos morreriam coatro centos, e sincoenta mil” pag. 453.
} 
pertence ao primeiro caso. A doutrina cristã prega que para Deus nada é impossível e a Bíblia e as Hagiografias fornecem inúmeros exemplos disso. ${ }^{126}$

A partir dos versos citados d'Os Lusíadas, apreende-se que as Batalhas de Ourique e de Salado diferem-se nos motivos que as causaram: a de Ourique é uma ofensiva dos Cristãos contra os Mouros que habitavam terras que aqueles consideravam suas por direito, e a de Salado é uma batalha defensiva dos Cristãos, contra o ataque dos Reis de Granada e do Marrocos às terras de Castela. No entanto ambas assemelham-se em dois aspectos: nos combatentes (são cristãos lutando contra mouros e mouros contra cristãos) e na justeza da causa; os cristãos agem justamente nas duas.

$\mathrm{Na}$ Batalha de Ourique os cristãos recuperam sua terra; na de Salado eles a defendem. Na Batalha de Ourique, querem os cristãos retomar suas terras e expulsar delas o "infiel” que encarna o mal. Na Batalha de Salado, agem os mouros erradamente, pois querem se apossar do que não lhes pertence. Sendo assim, lutam os cristãos por motivos justos e dignos: a defesa de suas terras e de sua Fé. E agem os mouros viciosamente, por cobiça, ganância e inveja. Devem estes ser enfrentados quando atacam e combatidos onde quer que estejam.

\section{e.5) em Calecute}

Em Calecute, Vasco da Gama e sua frota não enfrentam nenhuma batalha, porém são perseguidos, enganados e odiados pelos Mouros do local que pretendem que eles não consigam retornar à Portugal.

\section{Canto VII, 23}

"Chegada a frota ao rico senhorio,/ Hum português mandado logo parte,/ A fazer sabedor o Rei gentio/ Da vinda sua a tam remota parte:/ Entrando o mensageiro pelo Rio,/ Que ali nas ondas entra a não vista arte/ A cor, o gesto estranho, o trajo novo/ Fez concorrer a vello todo o povo"

O primeiro contato dos portugueses com os outros povos é sempre amigável. Eles almejam obter conhecimentos e estabelecer trocas comerciais. Hernani Cidade

\footnotetext{
${ }^{126}$ As sete pragas do Egito, a abertura do Mar Vermelho, os milagres de Jesus Cristo, a vida de São Vicente etc.
} 
afirma que João de Barros é um dos que defendem ser dever dos cristãos tratar a todos com cordialidade, em tempos de paz.

Aceitando embora que fossem violentos na guerra, não os dispensava das virtudes que os mostrassem capazes da missão que, em sua convicção, Deus lhes confiara - e entre essas virtudes, a da cordialidade e gentileza, indispensáveis às relações entre os homens, mesmo de diferente categoria hierárquica ${ }^{127}$.

Agindo com cortesia e generosidade, os portugueses conquistam o "poder anagógico da exemplaridade que convence e converte ${ }^{128}$." Além, obviamente, de garantir o comércio entre os locais "descobertos" e Portugal.

\section{Canto VII, 28}

"O Portugues aceita de vontade/ O que o ledo Monçaide lhe offerece/ Como se longa fora já a amizade,/ Coelle come e bebe, e lhe obedeçe/ Ambos se tornão logo da cidade,/ Para a frota, que o Mouro bem conheçe/ Sobem aa Capitaina, e toda a gente/

\section{Monçaide recebeo benignamente"}

Monçaide é um mouro nascido na Berberia e desde o primeiro contato com os portugueses em Calecute tornara-se amigo destes, servindo-lhes inclusive de intérprete. É o "sábio Mauritano", a quem poeta se refere no Canto VIII, 1.

No entanto, apesar das pacíficas intenções dos portugueses e do auxílio prestado por Monçaide, muitos contratempos enfrentados pelos portugueses em Calecute são narrados no poema. Os mouros se indispuseram contra os lusitanos e tentaram fazer com que o Samorim, governante de Calecute, os expulsasse de suas terras. O poeta assim se refere à esses mouros: Canto VIII, 51 "torpe seita"; Canto VIII, 56 "avaros Catuais"; Canto VIII, 58 "malina/ Gente"; Canto VIII, 76 “ Os Catuais corruptos, mal julgados"; Canto VIII, 88 "feros Maometanos"

\footnotetext{
${ }^{127}$ CIDADE, Hernani. A Literatura Portuguesa e a Expansão Ultramarina. Coimbra: Armênio Amado, Editor Sucessor, 1963. pag. 99.

${ }^{128}$ REBELO, Luis de Sousa. A Tradição Clássica na Literatura Portuguesa. Lisboa: Livros Horizonte, 1982.
} 
Estão eles contra os portugueses e suas ações corroboram para que o ódio que os move se explicite e os denuncie como viciosos. Quem age movido pela ira infundada, age viciosamente. "Ora, louvamos alguém que sente ira em função das razões certas, contra as pessoas certas, e também da maneira certa, no momento certo e pela duração certa" ${ }^{\prime 29}$. A ira dos mouros contra os portugueses não tinha razão de ser, pois estes nada fizeram contra eles. Os mouros mostram-se, pois, injustos, irascíveis e torpes.

\section{3 - Maomé e sua "Seita"}

Vimos até o presente momento que os mouros são vituperados no decorrer de todo o poema. São designados como torpes, falsos, inimigos, pérfidos etc. E o credo que professam também recebe vários epítetos injuriosos. No entanto não há personagem mais violentamente vituperado que Maomé. Vejamos como é construído o vitupério ao fundador da "Errada Seita".

Segundo Quintiliano:

Há quem tenha sido marcado pela infâmia após sua morte. (...) nós odiamos o pais dos criminosos; os fundadores de vilas são difamados também por terem transformado em Estado uma nação perniciosa aos outros, (...). Mas, para os vivos também, a opinião pública contém um testemunho dos seus modos, e sua boa ou má reputação justifica o elogio ou o vitupério. ${ }^{130}$

Embora Maomé não tenha fundado nenhuma vila, é ele o fundador de uma nova seita, perniciosa para os cristãos. Se, conforme Bluteau, definirmos "seita" considerando-se seu aspecto herético, Maomé será vituperado por ameaçar a ortodoxia .

Maomé figura, dessa maneira, como um falso e vicioso profeta. E o Islã, é a Lei maldita, a errada seita.

\footnotetext{
${ }^{129}$ ARISTÓTELES. Ética a Nicômaco. Pag. 134.

${ }^{130}$ Tradução nossa do seguinte trecho: “Et post mortem adjecta quibusdam ignomínia est, (...) família in posterum exemptum est, et parents malorum odimus; et est conditoribus urbium infame contraxisse aliquam perniciosam ceteris gentem, (...). Sed in viventibus quoque judicia hominum velut argumenta sunt morum, et honos aut ignominha veram esse laudem vel vituperationem probat" QUINTILIANO, Vol. 1, pag. 378.
} 
Torpe Mahamede: Canto I, 99 "Ho mesmo o falso Mouro determina,/ Que o seguro Christão lhe manda e pede,/ Que a Ilha he possuída da malina/ Gente, que segue o torpe Mahamede"

Falso Mahamede: Canto II 50- "Envejoso vereis o grão Mavorte/ Do peito Lusitano, fero e horrendo./ Do Mouro ali verão que a voz extrema/ Do falso Mahamede ao Ceo blasfema"

Vicioso Mahoma: Canto VII, 17- "Jugo de Reis diversos o constrange/ A várias leis: algus o vicioso/ Mahoma, algus os Idolos adorão,/ Algus os animais, que entre elles morão"

Errada seita: Canto I,57- "Qualquer então consigo cuyda, e nota/ Na gente, e na maneira desusada,/ E como os que na errada Seita crerão/ Tanto por todo o mundo se estenderão"

Lei Maldita: Canto IV, 99- "Não tens junto com tigo o Ismaelita,/ Com quem sempre terás guerras sobejas?/ Não segue elle do Arábio a ley maldita"

Lei Profana: Canto VII, 13- "Gregos, Traces, Armênios, Georgianos,/ Bradando vos estão, que o povo bruto/ Lhe obriga os caros filhos aos profanos/ Preceptos do alcorão (duro tributo!)"

Torpe seita: Canto VIII, 65- "Se os antigos delitos, que a malícia/ Humana cometeo na prisca idade,/ Nam causaram, que o vaso da niquícia,/ Açoute tão cruel da Christandade,/ Viera pôr perpétua inimicícia/ Na geraçam de Adão, co a falsidade,/ O poderoso Rei da torpe seita,/ Nam conceberas tu tão má sospeita”

Tal figuração era comum aos textos contemporâneos ao poema. Cardaillac ${ }^{131} \mathrm{diz}$ que nos século XVI vários lugares-comuns já estavam estabelecidos tais como o fato de Maomé ser indigno por impor o Alcorão pela força das armas e também por conquistar adeptos pela licenciosidade que permitia a eles. Outro lugar-comum era a crença de que todas as verdades contidas no Alcorão eram de origem cristã ou judaica.

\footnotetext{
${ }^{131}$ "Es evidente que cuando llega al siglo XVI ya se han formado lugares comunes: los cristianos denunciam la indignidade de Mahoma que impone el Corán por la espada y gana adeptos por permitirles toda licencia, las pocas verdade que encierra el Corán proceden de textos cristianos y judios" CARDAILLAC, Louis. Moriscos y Cristianos: um enfrentamiento polémico (1492-1640). México, FCE, 2004. pag 314
} 
Perez de Chinchon é um dos autores citados por Cardaillac. Ele afirma que Maomé mente quando se intitula profeta. Em seu livro Antialcorão ele expõe as quatorze qualidades comuns a todos os profetas e conclui que Maomé não possui nenhuma (exceto, talvez, a de haver predicado).

Afirma também que:

a ley de Mahoma no puede ser en ninguna manera ley de Dios por parte de quien le dio ser malo y engañador y gran pecador y falso y mentiroso propheta. (...) y que tu ley sea mentira, yo lo pruebo así: ella te dize que Mahoma fue propheta y embiado por Dios y que Dios le dio esta ley y todo esto es mentira: luego tu ley es mentira ${ }^{132}$

Também para Las Casas é Maomé um falso profeta: "La impiedad de los sarracenos se opone tambíen a la ley divina, pues veneran a un ímpio pseudopropheta, encenagado en el fango de todos los vícios, y practican tambíen ciertas ceremonias obscenas contra la ley natural" ${ }^{, 133}$.

Assim Bluteau define o seguidor da Lei de Maomé: "Mahometano: Que segue a ímpia, e infame ley de Mahoma"134.

Falso, ímpio e vicioso eram os epítetos injuriosos mais comumente aplicados à Maomé. Mas por vezes era ele também designado como anticristo. Assim João de Barros se refere a ele, nas primeiras palavras escritas em sua Ásia, quando narra a origem do maometismo "açoute da divina misericórdia"135

Alevantado em a terra de Arábia aquelle grãde antechristo

Mafamede, quasi nos annos de quinhentos noventa e três da nossa redençam, assy lavrou a fúria de seu ferro e fogo de sua infernal secta $^{136}$

\footnotetext{
${ }^{132}$ Citado por CARDAILLAC, L. Pag 345.

${ }^{133}$ Citado por MECHOULAN, Henry. El Honor de Dios. Barcelona: Editorial Argos Vergara, S.A, 1981. Pag. 191.

${ }^{134}$ BLUTEAU, Raphael, Vocabulario Portuguez e Latino, aulico, anatomico, architectonico... Coimbra: No Collegio das Artes da Companhia de Jesu, 1712

${ }^{135}$ BARROS, Joao de. Asia. Primeira Década. Pag 08.

${ }^{136}$ Idem, pag. 05 (grifos meus)
} 
Suas palavras sintetizam a figuração comumente utilizada pelos cronistas e poetas para se referir a Maomé, à sua seita e a seus seguidores.

\section{4 - Considerações Finais}

A partir do que foi abordado até aqui pode-se concluir que os vitupérios aplicados aos maometanos são predominantemente relativos aos aspectos anímicos de seu ethos; são caracterizados como viciosos tendo a covardia e a falsidade como principais vícios.

Acreditamos, todavia, que ao apontar os vícios dos maometanos, pretende Camões não apenas injuriá-los, destacando sua maldade e reprovando suas ações; mas também apresentar aos leitores exemplos de iniqüidade para assim melhor dar-lhes a conhecer a equidade. Nas palavras de Quintiliano: "pois é bom conhecer exatamente a iniqüidade, para melhor defender a equidade" ${ }^{\prime 137}$. Para se conhecer a virtude e querer imitá-la, pode-se apresentá-la descrevendo feitos virtuosos de ilustres homens. Mas pode-se também destacar o que é vicioso a fim de se explicitar o que é reprovado e o que deve ser evitado.

Ao compor a sua epopéia Camões não se descuidou dos preceitos retóricopoéticos que regulavam as produções letradas de seu tempo. E um dos principais preceitos que seguiu foi o que diz que todo o discurso deve tornar aceitável uma proposição ou causa. Para atingir tal objetivo, o poeta se valerá de argumentos dirigidos à razão ou ao coração do leitor. Dessa maneira o discurso poderá cumprir o seu triplo ofício de deleitar, educar e mover. O épico, como imitação de feitos virtuosos, suscita a emulação das virtudes heróicas e atende, dessa maneira, à utilitas horaciano inserida na moralidade cristã.

Os Lusíadas ao narrar os feitos virtuosos dos portugueses ao longo de vários séculos, seja na viagem até as Indias, seja na narração da História de Portugal, fornece à seus leitores exempla. Para Cícero a História é a mestra da vida; mas para os poetas épicos é a epopéia mais eficaz, pois deleita, ensina e move, se aproveitando dos fatos históricos para melhorá-los, por moralidade.

137 “Nam et iniquorum ratio noscenda est, ut melius aequa tueamur” QUINTILIANO. Vol 1. Pag. 400. 
Encerramos esse trabalho citando Hernani Cidade, a quem admiramos pelo entusiasmo e com quem concordamos quando ele afirma que

"Camões não escreveu o seu poema no propósito de fascinar as imaginações com histórias deleitosas. (...) No momento em que a gloriosa grandeza da Pátria, que a sua mocidade conheceu no zênite, declinava e ameaçava submergir-se, procura ele fixar para a imortalidade os clarões ainda não extintos, escarmentando para a continuação do esforço épico ou ao menos para a defesa da dignidade coletiva os epígonos dos heróis." 138

${ }^{138}$ CIDADE, Hernani. A Literatura Portuguesa e a Expansão Ultramarina. Coimbra: Armênio Amado, Editor Sucessor, 1963. Pag. 347. 


\section{Referências Bibliográficas}

ARISTÓTELES. Poética. Coleção Os Pensadores. São Paulo: Abril Cultural, 1977.

Retórica. Lisboa: Imprensa Nacional - Casa da Moeda, 1998.

ARTAZA, Elena. El Ars Narrandi en el siglo XVI español. Teoria y Practica. Bilbao: Universidade de Deusto, 1989.

BARRETO, Luís Filipe. Descobrimentos e Renascimento: Formas de ser e pensar nos seculos XV e XVI. Lisboa: Imprensa Nacional-Casa da Moeda, 1983.

BARROS, João de. Ásia. Dos Feitos que os Portugueses fizeram no descobrimento e conquista dos mares e terras do Oriente. Primeira Década. Coimbra: Imprensa Nacional - Casa da Moeda, 1932.

BLOCH, Marc. Etymologie et définitions diverses du nom de Maure. In: Bulletins et Mémoires de la Société d'anthropologie de Paris, Vº́rie. Tome 4, 1903. pp. 624-628. Disponível em: http:// www.persee.br.

BOXER, Charles. A Igreja e a Expansão Ibérica (1440-1770). Lisboa: Edições 70, s.d. O império marítimo português (1415-1825). São Paulo: Companhia das Letras, 2002.

BLUTEAU, Raphael. Vocabulario Portuguez e Latino, Aulico, Anatomico, Architectonico, Bellico, Botanico, Brasilico, Comico, Critico, Chimico, Dogmatico, Dialectico, Dendrologico, Ecclesiastico, Etymologico, Florifero, Forense, Fructifero, Geographico, Geometrico, Gnomonico, Hydrographico, Homonymico, Hierologico, Ichtyologico, Indico, Isagogico, Laconico, Liturgico, Lithologico, Medico, Musico, Metereologico, Nautico, Numerico, Neoterico, Ortographico, Optico, Ornithologico, Poetico, Philologico, Pharmaceutico, Quiddotativo, Qualitativo, Quantitativo, Rethorico, Rustico, Romano, Symbolico, Synonimico, Syllabico, Theologico, Terapeutico, Technologico, Uranologico, Xenophonico e Zoologico, Authorizado com exemplos dos melhores escritores Portuguezes e Latinos... Coimbra: No Collegio das Artes da Companhia de Jesu, 1712.

CAMÕES, Luis de. Os Lusíadas. Lisboa: em casa de Antonio Gõçalvez, 1572. (edição quinhentista disponível na Biblioteca Digital da Biblioteca Nacional de Lisboa no endereço eletrônico: http://purl.pt/1

CAMÕES, Luis de. Os Lusíadas. Edição fac-similar em comemoração ao IV centenário de Os Lusíadas e Sesquicentenário da Independência. Rio de Janeiro: Academia Brasileira de Letras - Xerox Brasil. 1972. 
CARDAILlAC, L. Moriscos y Cristianos. Un enfrentamiento polémico (1492-1670). Mexico: FCE, 2002.

[CÍCERO]. Retórica a Herênio. Tradução e Introdução Ana Paula Celestino Faria e Adriana Seabra. São Paulo: Hedra, 2005.

Cancioneiro Geral de Garcia de Resende. Vol. II. Fixação do Texto por Aida Fernanda Dias. Lisboa: Imprensa Nacional-Casa da Moeda, 1990.

CASTRO, Américo. España en su História. Barcelona: Editorial Critica, 2001.

CURTIUS, E. Literatura européia e idade média latina. São Paulo: Hucitec, Edusp, 1996.

CIDADE, Hernani. Camões - o Épico. Lisboa: Editorial Presença, 2003.

A Literatura Portuguesa e a Expansão Ultramarina. Coimbra, Armênio Amado, Editor Sucessor, 1963.

CURTO, Diogo Ramada. A Literatura e o Império: Entre o Espírito Cavaleiroso, as Trocas da Corte e o Humanismo Cívico. In: BETHENCOURT, Francisco e CHAUDHURI, Kirti. História da Expansão Portuguesa. Vol. 1. A Formação do Império (1415-1570). Lisboa: Círculo de Leitores, 1997.

DOMINGUES, José D. Garcia. A Concepção do Mundo Árabe-Islâmico n’Os Lusíadas. In: Garcia de Orta. Revista da Junta de Investigação do Ultramar. Número especial 1-608, Lisboa, 1972.

FARINHA, Antonio Dias. Os árabes nos antigos relatos portugueses do Indico.

Finisterra, XL, 79, 2005, pags. 151-160. Disponível em:

http://www.ceg.ul.pt/finisterra/numeros/2005-79/79_12.pdf. Acessado em: outubro de 2010.

GALVÃO, Duarte. Crónica de El-Rei D. Afonso Henriques. Lisboa: Imprensa Nacional-Casa da Moeda, 1995.

GOIS, Damião de. Cronica do Felicíssimo Rei D. Manuel. Parte III. Nova edição conforme a primeira de 1566. Coimbra: Por ordem da Universidade, 1954.

HANSEN, João Adolfo. A Sátira e o Engenho. Gregório de Matos e a Bahia do Século XVII. São Paulo: Ateliê Editora; Campinas: Editora da Unicamp, 2004.

IBARRA, Miguel Angel de Bunes. Los Moriscos em el pensamiento histórico. Madrid: Ediciones Catedra, 1973.

MATTOSO, José (org). História de Portugal. Vol.1 e Vol.2. Lisboa: Editorial Estampa, 1987.

MECHOULAN, Henry. El Honor de Dios. Barcelona, Editorial Argos Vergara, 1981. 
MUHANA, Adma. A Epopeia em Prosa Seiscentista: uma definição de gênero. São Paulo: Fundação Editora da UNESP, 1997.

OROZCO, Sebastián de Covarrubias. Tesoro de la Lengua Castellana o Espanola. (1611). Madrid: Editorial Castalia, 1995.

PIDAL, Ramón Menendez. De Primitiva Lírica Española y Antigua Épica. Madrid: Espalsa-Calpe, SA, 1968.

PINA, Rui de. Crônicas. Porto: Lello e Irmão Editores, 1977.

POUILLON, François. Simplification ethnique em Afrique Du Nord: Maures, Arabes, Berbères (XVIIIe-XXe siècles). in: Cahiers d'études africaines. Vol. 33 No 129. Mesurer la différence: l'anthropologie physique. PP. 37-49. Disponível em: http://www.persee.fr

QUINTILIEN. Intituition Oratoire. Vol 1 e 2. Texte révu et trad. avec introd. et notes par Henri Bornècque. Paris: Librairie Garnier Frères, 1934.

REBELO, Luis de Sousa. A Tradição Clássica na Literatura Portuguesa. Lisboa: Livros Horizonte, 1982.

RODRIGUES, José Maria. Fontes dos Lusíadas. Lisboa: Academia das Ciências de Lisboa, 1979.

SCATOLIN, Adriano. A Invenção no Do Orador de Cícero: um estudo à luz de $\underline{A d}$ Familiares I, 9, 23. Tese de Doutorado. Faculdade de Filosofia, Letras e Ciências Humanas da Universidade de São Paulo. São Paulo, 2009.

SICROFF, Albert. Los estatutos de limpieza de sangre. Madrid: Taurus Ediciones, 1985.

TOLAN, John. Les Sarrasins: L'islam dans l'imagination européenne au Moyen Âge. Paris, AUBIER, 2003.

VICENTE, Gil. As Obras de Gil Vicente. Vol. 1. Centro de estudos de Teatro. Lisboa: Imprensa Nacional - Casa da Moeda, 2002. 